\title{
Climate anomalies associated with the occurrence of rockfalls at high-elevation in the Italian Alps
}

\author{
Roberta Paranunzio ${ }^{1}$, Francesco Laio ${ }^{1}$, Marta Chiarle ${ }^{2}$, Guido Nigrelli ${ }^{2}$, and Fausto Guzzetti ${ }^{3}$ \\ ${ }^{1}$ Department of Environment, Land and Infrastructure Engineering, Politecnico di Torino, Torino, Italy \\ ${ }^{2}$ Research Institute for Geo-hydrological Protection, National Research Council (CNR IRPI), Torino, Italy \\ ${ }^{3}$ Research Institute for Geo-hydrological Protection, National Research Council (CNR IRPI), Perugia, Italy \\ Correspondence to: Roberta Paranunzio (roberta.paranunzio@polito.it)
}

Received: 29 March 2016 - Published in Nat. Hazards Earth Syst. Sci. Discuss.: 4 April 2016

Revised: 13 July 2016 - Accepted: 22 August 2016 - Published: 12 September 2016

\begin{abstract}
Climate change is seriously affecting the cryosphere in terms, for example, of permafrost thaw, alteration of rain/snow ratio, and glacier shrinkage. There is concern about the increasing number of rockfalls at high elevation in the last decades. Nevertheless, the exact role of climate parameters in slope instability at high elevation has not been fully explored yet. In this paper, we investigate 41 rockfalls listed in different sources (newspapers, technical reports, and CNR IRPI archive) in the elevation range 1500$4200 \mathrm{~m}$ a.s.l. in the Italian Alps between 1997 and 2013 in the absence of an evident trigger. We apply and improve an existing data-based statistical approach to detect the anomalies of climate parameters (temperature and precipitation) associated with rockfall occurrences. The identified climate anomalies have been related to the spatiotemporal distribution of the events. Rockfalls occurred in association with significant temperature anomalies in $83 \%$ of our case studies. Temperature represents a key factor contributing to slope failure occurrence in different ways. As expected, warm temperatures accelerate snowmelt and permafrost thaw; however, surprisingly, negative anomalies are also often associated with slope failures. Interestingly, different regional patterns emerge from the data: higher-than-average temperatures are often associated with rockfalls in the Western Alps, while in the Eastern Alps slope failures are mainly associated with colder-than-average temperatures.
\end{abstract}

\section{Introduction}

The recent decades have seen a pronounced warming in global climate, primarily at high elevations and high latitudes (Schär et al., 2004). Temperature across European Alps has increased of about $1.4^{\circ} \mathrm{K}$ per century over the period 1906 2005, which is more than double the global average (Brunetti et al., 2009) and further increases are expected according to global and regional climate models (Beniston, 2006; Stocker et al., 2013). At the same time, an increasing trend of precipitation was observed in the northern hemisphere, with significant regional variations (Auer et al., 2007). Almost everywhere, the cryosphere is degrading rapidly in response to air temperature warming (Stocker et al., 2013). Glacier shrinkage and permafrost degradation, i.e. the decrease in the thickness/areal extension of permafrost (Stocker et al., 2013), are expected to significantly worsen the geotechnical and mechanical properties of rock, debris, and soils in high-mountain areas (Noetzli et al., 2006; Kääb et al., 2007; Harris et al., 2009). In particular, permafrost climate-induced degradation affects the stability of steep rock walls at different timing, magnitude, and depths, affecting the thermal and hydraulic conditions of the rock mass (Gruber and Haeberli, 2007) e.g. by altering the active layer thickness and fractures conditions by reducing the shear strength (Davies et al., 2001). Permafrost and in general cryosphere degradation might play a role for the growing number of slope failures at high elevation that has been documented since the beginning of the 21st century (Chiarle and Mortara, 2008; Stoffel et al., 2014). However, the exact role of climate parameters and their influence on the preparation and initiation of slope fail- 
ure remains poorly understood. While many studies focus on rainfall-induced landslides, which have been performed for different geographic settings and elevation ranges (Guzzetti et al., 2008; Brunetti et al., 2015), the link between landslide occurrence and temperature, in combination or not with precipitation, has been little explored.

Only recently, following the summer 2003 heatwave in Europe, the role of temperature in the occurrence of slope failures has been considered thoughtfully (Gruber et al., 2004; Huggel et al., 2010). Authors have speculated on possible relationships between changes of the mean air temperature and an increased activity of slope failures (Ravanel and Deline, 2011) or have explored links between extreme air temperature events and rockfall occurrence (Allen and Huggel, 2013).

Paranunzio et al. (2015) proposed a method to investigate the possible relationships between the different climate variables and the triggering of slope failures and tested their method on different types of slope instabilities occurred in the Western Italian Alps. This method proved to be able to discriminate slope failures caused by climate factors and to point out the climate anomaly (or anomalies) that may be responsible for their occurrence.

In this paper, we use an advanced version of the method proposed by Paranunzio et al. (2015) to analyse a catalogue of 41 rock-slope failures occurred from 1997 to 2013 at high elevation in the Italian Alps in the absence of an evident rainfall, seismic, or anthropic triggers.

Our focus is on temperature, which plays an important role in cryosphere dynamics. Thus, in this work, we concentrate on those events occurred without an evident precipitation trigger. The aim is to verify the hypothesis that climate warming can be deemed responsible for increased slope instability in recent years, highlighting the role of temperature, in association or not with precipitation.

Our catalogue includes rockfalls and rock avalanches, with volume in the range $10^{2}-10^{6} \mathrm{~m}^{3}$ (hereinafter, "rockfall" is used to refer to both rockfalls and rock avalanches). Our purpose is to provide a statistically based analysis of the main climate variables in the period preceding the rockfalls, aimed to detect anomalous values that can be deemed responsible for slope failure. We focus first on daily climate variables, including air temperature, the variation in the air temperature, and precipitation (liquid and solid). We then perform a bivariate analysis that includes the climate anomalies identified in the previous step and the spatiotemporal characteristics of the rockfalls in the catalogue (including elevation, aspect, volume, and season of occurrence). Finally, we discuss the results in a context of climate warming, speculating on the possible causes of rockfall occurrence.

\section{Study area}

We focus on the Italian side of the European Alps. The Italian Alps extend for about $1200 \mathrm{~km}$ and cover $5200 \mathrm{~km}^{2}$, $27.3 \%$ of the European Alps. The tectonic units of the European Alps results in four parts: Helvetic, Penninic, Eastern, and Southern Alpine. Western Alps tend to be more compressed than the eastern sector due to the collision between the African and European plates. As a consequence, the western sector hosts the highest peaks, while the eastern sector has the greatest diameter. The Periadriatic Fault divides the Southern Alpine from the other three sectors. Permian volcanic rocks and Mesozoic sediments (limestones, dolomites, and volcano-detritic facies) overlap the crystalline basement. The Dolomites relief, dominated by mountain ridges up to 3400 m a.s.l., is mainly composed by Mesozoic sediments. The Western Italian Alps are mainly characterized by Penninic nappes; here, limestones, gneiss, and granites predominate (Fitzsimons and Veit, 2001).

Glaciers on the Italian flank of the Alps are located mainly in the western and central regions. From the Little Ice Age (LIA) to 2000s, glaciers on the Alpine relief suffered a reduction of almost $50 \%$ (Zemp et al., 2006) with a significant peak on the western Italian side (Nigrelli et al., 2015).

According to the Alpine Permafrost Index Map, which shows a qualitative index describing how likely permafrost is to exist in the European Alps (Boeckli et al., 2012), 13 rockfalls occurred where permafrost is expected in nearly all conditions, while 18 occurred in areas where we expect permafrost only in cold (7) and favourable conditions (11). From studies carried out in the European Alps, permafrost on shaded slopes is present above $2500 \mathrm{~m}$, whereas on S-facing slopes it is found above $3500 \mathrm{~m}$ (Fischer et al., 2012; Gruber et al., 2004). Climate in the European Alps depends on the complex interaction between orography and the general circulation of the atmosphere (Beniston, 2006). As a result, the Italian Alps show a high variability in the spatial distribution of temperature and precipitation, at regional and local scales (Auer et al., 2007; Brunetti et al., 2009). Referring to the regional scale, the climate regimes of the Western and Eastern Italian Alps differ significantly.

In relation to the 30-year climate normals (1981-2010), the total annual precipitation that occurs in mountain areas of the Western and Eastern Italian Alps is about 850 and $1050 \mathrm{~mm}$, respectively. Minimum (maximum) annual temperature is, respectively, $-3\left(5^{\circ} \mathrm{C}\right)$ in the Western and -1 $\left(8^{\circ} \mathrm{C}\right)$ in the Eastern Italian Alps (Esposito et al., 2014). These temperatures refer to areal values, extrapolated using known observations recorded from the weather stations located in the area of interest. 


\section{Data}

\subsection{Rockfall catalogue}

Our catalogue lists 41 rockfalls occurred in the 17-year period between 1997 and 2013 at high elevation (above 1500 m a.s.l.) in the Italian Alps (Table 1). The 41 rockfall events concentrate in two main geographical clusters. A first cluster corresponds to rockfalls occurred in the Western Italian Alps; a second cluster includes the rockfalls occurred in the Eastern Italian Alps. Only one case (the Thurwieser rockfall of 18 September 2004) is located in the Central Italian Alps (Fig. 1). More specifically, the rockfalls concentrate in four mountain areas, including (i) the Mont Blanc Massif (4808 m a.s.l.), (ii) the Matterhorn Peak (4478 m a.s.l.), (iii) the Monte Rosa Massif (4637 m a.s.l.), and (iv) the Dolomites (maximum elevation: $3348 \mathrm{~m}$ a.s.l., Marmolada mountain group).

We constructed the catalogue consulting different sources, including national and local newspapers, journal articles, technical reports, and CNR IRPI archives (Fig. 2). For most of the events (25) information on the slope failures was obtained in the framework of a national project aimed to collect information on slope failures in the period from 2000 and 2013 (Brunetti et al., 2015). Information on the magnitude is available for 26 rockfalls $(63 \%)$, which range in volume between $10^{2}$ and $2 \times 10^{6} \mathrm{~m}^{3}$ (Table 1 ). The information on the volume comes from different sources; thus it is inhomogeneous for accuracy and level of detail. This is crucial, given the hankering for estimating rockfalls magnitude. In most cases, we do not know how volumes have been estimated. Nonetheless, a prevalence of large volume events, i.e. above or equal to $10^{4} \mathrm{~m}^{3}$, is detected in the western while small events, i.e. below $10^{4} \mathrm{~m}^{3}$, prevail in the eastern sector (respectively 8 out of 14 and 8 of 12 events with available magnitude data). All the events were located geographically using Google Earth. To select the events listed in the catalogue, we considered the availability of accurate information on the location and the time of occurrence of the failure as well as the availability of a long-term record of climate data covering the date of the event.

The sample size that we used for this work is relatively limited. This is due in part to the fact that the landslides that we are looking at, i.e. rockfalls occurring at high elevation and not triggered by rainfall, earthquakes, or human activities, are only a small subset of all landslides occurring in the Italian Alps (see e.g. Stoffel et al., 2014; Brunetti et al., 2015). In addition, the acquisition of information about slope failures in remote areas such as high mountains is often difficult. Moreover, we are aware of the fact that our dataset may include inhomogeneities. Small-volume events are usually reported only if they caused some relevant damage and, for this reason, they are probably underrepresented in the dataset. Summer events are documented more easily than those occurring in the other seasons. Many of the documented rockfalls occurred in the most famous mountain ranges (Mont-Blanc, Monte Rosa, Dolomites), and this is due in part to the high frequentation and to increased media attention in these mountains.

\subsection{Climate data}

We considered climate data obtained from 87 meteorological stations pertaining to different networks in the Italian Alps, including networks managed by the Regional Environmental Protection Agencies (ARPA) in Piemonte, Lombardia and Veneto regions, the Centro Funzionale of the Regione Autonoma Valle d'Aosta, the Hydrographic Office of the Provincia Autonoma di Bolzano, and Meteotrentino, in the Provincia Autonoma di Trento. We used different types of climate data, including (i) mean, minimum, and maximum daily air temperature and (ii) daily cumulated precipitation. In the Italian Alps, meteorological stations located above $1500 \mathrm{~m}$ a.s.l. are rare, and many of them were installed only recently. Therefore, climate records in high-mountain areas are limited and have a short duration in the study area. The limited geographical and temporal distribution of the climate information is the main constraint for the analysis of the climate conditions associated with the occurrence of slope failures at high elevation in the Italian Alps. For this reason, the first requirement for the selection of the meteorological stations for our analyses was the availability of a climate record covering the date of the failure and 90 days before it. We then considered only meteorological stations with a climate record exceeding 10 years. Since the elevation of the weather station is as important as its distance from the detachment area, weather stations have been selected in order to be close to it in terms of altitude and planimetric distance. In the end, we used climate data from a total of 27 meteorological stations (Table 2); we checked the quality of all the climate data, to identify and remove possible erroneous values (WMO, 2011).

\section{Method}

For our work, we exploited the method proposed by Paranunzio et al. (2015), which consists in a bottom-up statistical method for the identification of possible anomalous values of one or more climate variables $(V)$ on the occasion of slope instability events. The idea behind the method is to compare the climate conditions in the period preceding the failure to the climate conditions typical for the area where the failure has occurred. Eventual outliers of the climate variables prior to the occurrence of a slope failure may be considered related to (and possibly responsible for) the preparation and/or the initiation of the slope instability. The method is illustrated in Paranunzio et al. (2015): here we give a synthetic description of the main steps of the method, with special attention to the variations and improvements introduced in this work. Please note that, hereinafter, the term "date" is used to refer to the 


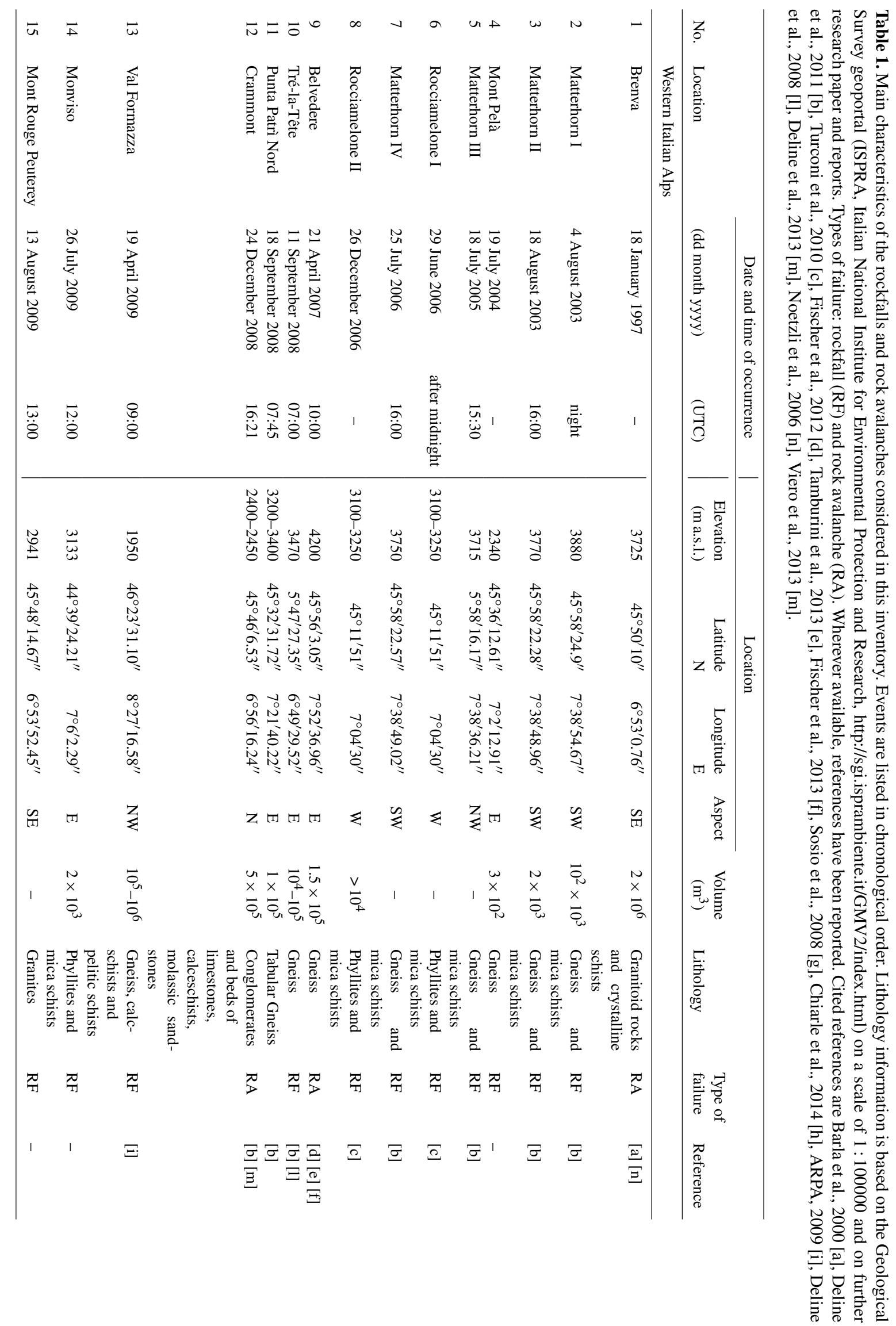




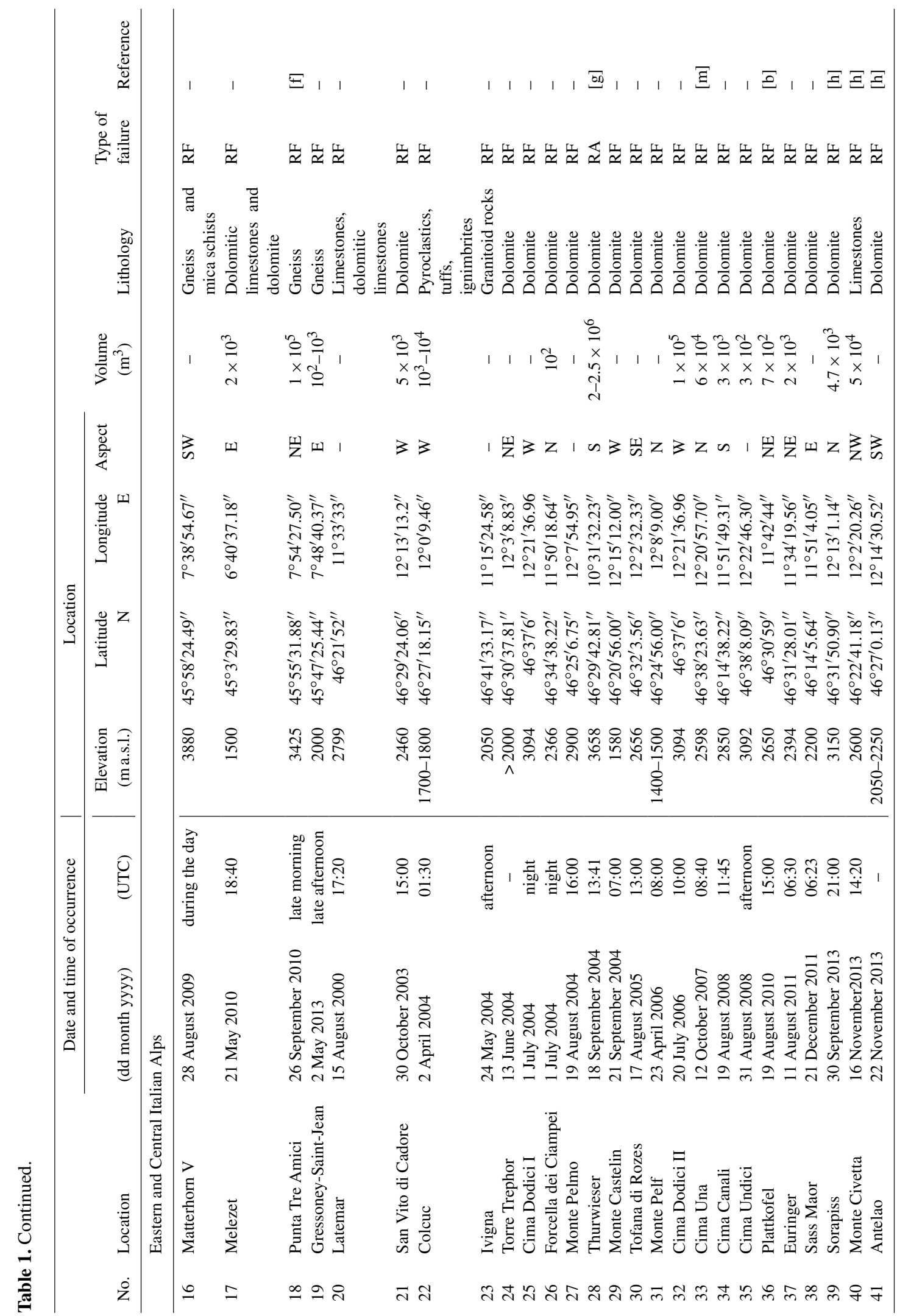




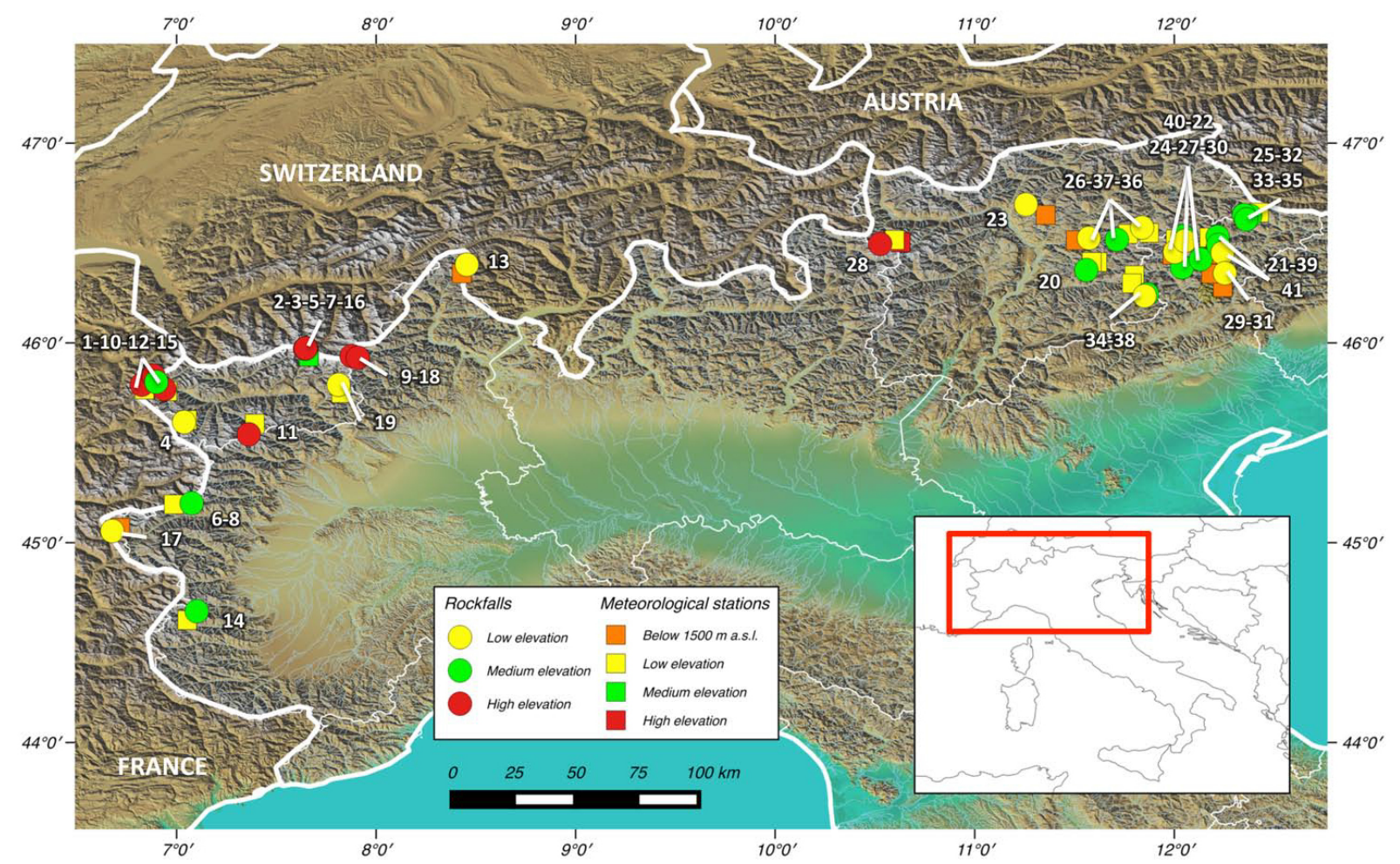

Figure 1. Map showing 41 events included in the inventory (dots) and of the 27 meteorological stations used in the study (squares). Events and meteorological stations are coloured differently according to elevation. Yellow dots/squares represent events/meteorological stations at low elevation (1500-2400 m a.s.1.); green dots/squares represent events/meteorological stations at medium elevation (2400-3300 m a.s.1.); red dots/squares represent events/meteorological stations at high elevation (3300-4200 ma.s.1.); meteorological stations located below $1500 \mathrm{~m}$ a.s.l. are in orange. Events are numbered according to Table 1.

exact date of failure (e.g. 15 May 2004), while "day" is used for the calendar date, i.e. the date without the year (e.g. 15 May).

The climate variables $V$ to be considered for statistical analysis were selected, including the air temperature $T$, the variation in the air temperature $\Delta T$ (i.e. the difference in the air temperature between the day of the failure and the previous day(s)), and precipitation $R$. We analysed the mean air temperatures $T_{\text {mean }}$ as in Paranunzio et al. (2015), and we also considered the minimum $\left(T_{\min }\right)$ and the maximum $\left(T_{\max }\right)$ air temperatures to obtain a more comprehensive picture of air temperature conditions before the slope failure.

- $V$ is a time-aggregated variable, and the aggregation time must be decided. In this work, we aggregated the temperature and precipitation measurements at the daily, weekly, monthly, and quarterly scale. In other words, we calculated the average of the daily values for $T_{\text {mean }}, T_{\max }, T_{\min }$, and the cumulated values of $R$ for $1,7,30$, and 90 days before the date/day of failure, including the date/day of failure. With regard to $\Delta T$, we considered time delays of 1,3 , and 6 days, i.e. the difference in temperature between the date/day of the failure and the previous 1,3 , and 6 days. As an example, if the failure occurred on 15 May, $\Delta T_{1}$ will be the difference in daily air temperature between 15 and 14 May, $\Delta T_{3}$ will be the difference in daily air temperature between 15 and 12 May, and $\Delta T_{6}$ will be the difference in daily air temperature between 15 and 9 May.

- The value of $V$ for the date of the failure was then compared with a reference sample including $n$ values, measured at the same reference meteorological station(s): we considered that a sample to be adequate for such a comparison if $n \geq 10$. In the ordered sample, $V_{(i)}$ is the $i$ th value, $i=1 \ldots n$. When selecting the most suitable reference sample, we need to consider the seasonality of the climate variable. In our study area, seasonality is particularly important for the air temperature $T$, and we thus compared the temperature recorded before the rockfall event with the temperature of a reference sample that included the same period. As an example, if a rockfall occurring at a given site on 15 September 2014, when we consider the average air temperature $(T)$ in the week before the failure (i.e. the average value of $T$ from 9 to 15 September 2014), the reference sample will include all temperature data aggregated at the weekly scale for the same period of the year, i.e. the average 

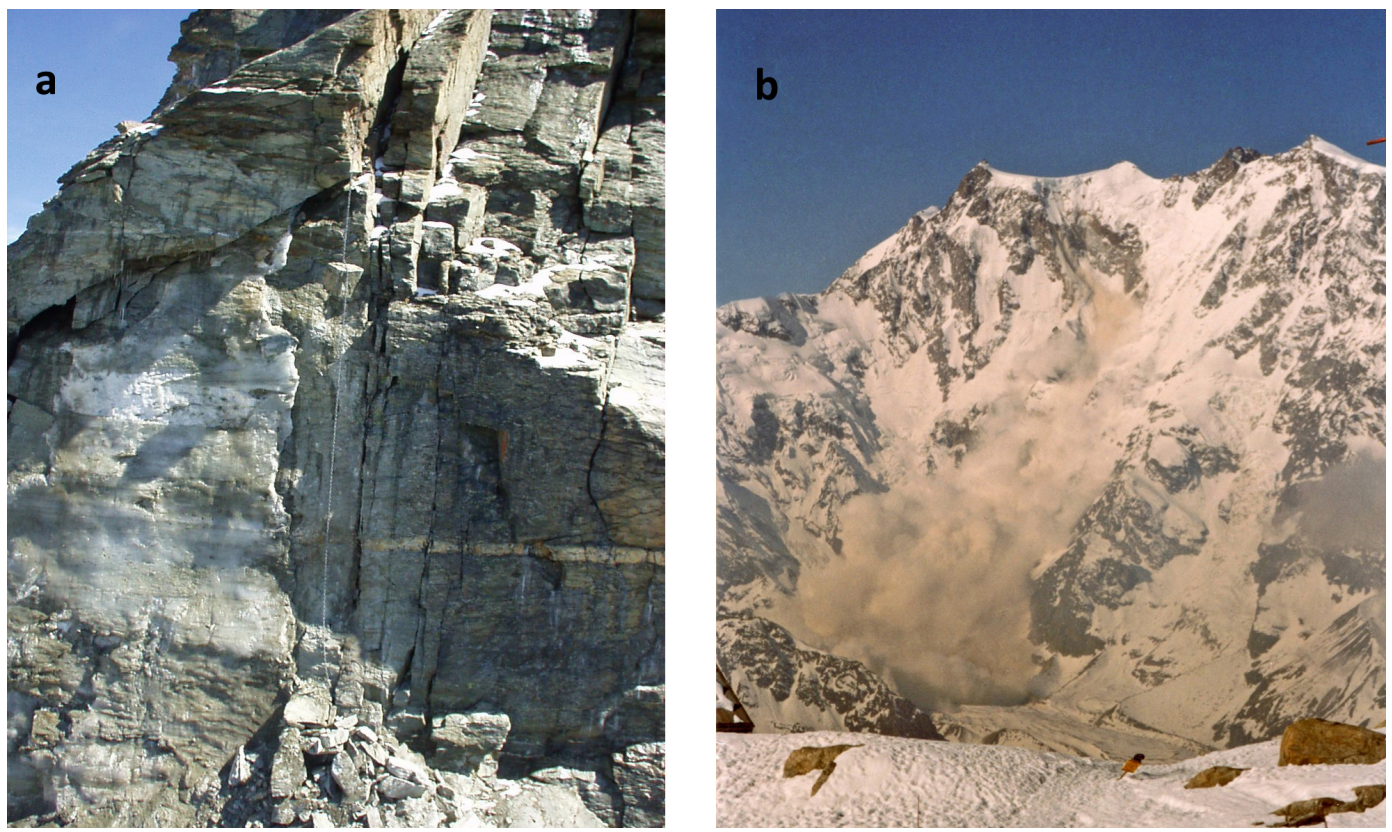

Figure 2. Selected examples of rockfall events. (a) Detachment area of the Matterhorn II rockfall (18 August 2003), with the ice lens (on the left) exposed by the collapse of the rock mass; photo source: L. Trucco. (b) Belvedere rock avalanche (21 April 2007); photo source: F. Bettoli.

value of $T$ in the period from 9 to 15 September for each year in the available historical record for the same reference meteorological station. For precipitation $(R)$ and the variation in the daily air temperature $(\Delta T)$, the reference sample is extended to include data registered in the 90-day period centred on the day of the failure (e.g. if the failure occurred on 22 November, we consider data in the previous and following 45 days, i.e from 8 October to 6 January). This procedure allows obtaining a larger reference sample and thus increases the robustness of the obtained results. This is particularly important for $R$, since precipitation is an intermittent process and not all years in the record necessarily have an $R$ value recorded for the period of interest. For our analysis, we used the climate data recorded at the reference stations, and we did not transpose (extrapolate) the temperature or precipitation measurements from the meteorological station to the location (geographical position and elevation) of the detachment zone of the rockfall. In fact, the application of a constant lapse rate would merely entail a translation of all values, without affecting the estimate of the probability associated with $V$.

- Finally, the non-exceedance probability $P(V)$ for the climate variable $V$ is calculated, where $P(V)=$ $i /(n+1)$, if $V>V_{(i)}$. We hypothesise that variables with an associated $P(V) \leq \alpha / 2$ (negative anomaly) or $P(V) \geq 1-\alpha / 2$ (positive anomaly) can be considered relevant factors for the preparation/initiation of rockfalls. The choice of the significance level $\alpha$ is a mat- ter of finding the best compromise between the necessity to reduce the probability to incur in a type I error (the probability to reject the null hypothesis given that is true) and a type II error (the failure to reject a false null hypothesis). In this case, the null hypothesis could be formalised as "the variable $V$ did not influence the rockfall triggering". Given that the former probability increases with increasing significance levels, while the latter decreases and considering that in the present case, in our opinion, type I error is less impacting that type I error, we decided to increase the significance level to 0.2 . Thus, in this way, we perform a standard $10 \%$ significance test on each of the tails of the distribution (negative or positive anomalies).

In addition to these analyses, for this work we performed a bivariate analysis to take into account additional factors that, in combination with climate anomalies, can help understanding the processes leading to slope failure. Here we give a synthetic description of the main steps of the procedure.

To describe the spatial and temporal distribution of the rockfalls listed in the inventory, we considered the following factors: (i) season of occurrence, (ii) mean elevation of the detachment zone, (iii) probability of permafrost occurrence, and (iv) magnitude of the event.

- The temporal distribution of the events was analysed considering the season of occurrence. Rockfall events were divided in four seasonal classes, i.e. spring, summer, autumn, and winter. In relation to the elevation of the detachment zones, the events were divided into 
Table 2. Main characteristics of the meteorological stations considered in this study. Only meteorological stations representing the best compromise between the requirements mentioned in Sect. 3.2 (i.e. covering the failure date, long-term dataset, low distance from the failure area) are displayed. No.: failure point numbers (from Table 1) associated with the meteorological stations; variables recorded at the stations: $T$ (temperature), $\Delta T$ (temperature variation between the day of the failure and the days before), and $R$ (precipitation). Data source: ARPA Piemonte, 2014 (PIE); ARPA Veneto, 2014 (VEN); Centro Funzionale - Regione Autonoma Valle d'Aosta, 2014 (VDA); Ufficio Idrografico - Provincia Autonoma di Bolzano, 2014 (BUI); Meteotrentino, 2014 (MET).

\begin{tabular}{|c|c|c|c|c|c|c|}
\hline Station name & $\begin{array}{l}\text { Location } \\
\text { elevation } \\
\text { (m a.s.l.) }\end{array}$ & $\begin{array}{r}\text { Observation period } \\
\text { latitude } \\
(\mathrm{N})\end{array}$ & $\begin{array}{r}\text { Data source } \\
\text { longitude } \\
(\mathrm{E})\end{array}$ & $\begin{array}{l}\text { Failure point } \\
\text { (years) }\end{array}$ & & (no.) \\
\hline \multicolumn{7}{|l|}{ Western Italian Alps } \\
\hline Barcenisio & 1525 & $45^{\circ} 11^{\prime} 30.34^{\prime \prime}$ & $6^{\circ} 59^{\prime} 6.05^{\prime \prime}$ & 1994-2013 & PIE & $6-8$ \\
\hline Formazza-Bruggi & 1226 & $46^{\circ} 20^{\prime} 51.60^{\prime \prime}$ & $8^{\circ} 25^{\prime} 43.67^{\prime \prime}$ & 1999-2013 & PIE & 13 \\
\hline Gressoney-Saint-Jean-Weissmatten & 2038 & $45^{\circ} 44^{\prime} 54.41^{\prime \prime}$ & $7^{\circ} 49^{\prime} 30.26^{\prime \prime}$ & 2003-2013 & VDA & 19 \\
\hline Cogne-Lillaz & 1613 & $45^{\circ} 35^{\prime} 43.03^{\prime \prime}$ & $7^{\circ} 23^{\prime} 29.19^{\prime \prime}$ & 2002-2012 & VDA & 11 \\
\hline Lex Blanche & 2162 & $45^{\circ} 45^{\prime} 58.86^{\prime \prime}$ & $6^{\circ} 50^{\prime} 17.84^{\prime \prime}$ & 2002-2012 & VDA & 15 \\
\hline Passo del Moro & 2820 & $45^{\circ} 59^{\prime} 53^{\prime \prime}$ & $7^{\circ} 58^{\prime} 39$ & 1988-2014 & PIE & $9-18$ \\
\hline Pontechianale & 1575 & $44^{\circ} 36^{\prime} 43.02^{\prime \prime}$ & $7^{\circ} 03^{\prime} 9.07^{\prime \prime}$ & 1993-2013 & PIE & 14 \\
\hline Prerichard & 1353 & $45^{\circ} 4^{\prime} 29.91^{\prime \prime}$ & $6^{\circ} 42^{\prime} 59.17^{\prime \prime}$ & 1990-2013 & PIE & 17 \\
\hline Pré-Saint-Didier-Plan Praz & 2044 & $45^{\circ} 45^{\prime} 28.76^{\prime \prime}$ & $6^{\circ} 57^{\prime} 9.71^{\prime \prime}$ & 1993-2012 & VDA & $1-10-12$ \\
\hline Valgrisenche-Menthieu & 1859 & $45^{\circ} 34^{\prime} 0.24^{\prime \prime}$ & $7^{\circ} 12^{\prime} 30.19^{\prime \prime}$ & 2001-2012 & VDA & 4 \\
\hline Valtournenche-Lago Goillet & 2526 & $45^{\circ} 55^{\prime} 53.52^{\prime \prime}$ & $7^{\circ} 39^{\prime} 45.46^{\prime \prime}$ & 1942-2012 & VDA & $2-3-5-7-16$ \\
\hline \multicolumn{7}{|l|}{ Eastern Italian Alps } \\
\hline Campo di Zoldo & 884 & $46^{\circ} 20^{\prime} 47.68^{\prime \prime}$ & $12^{\circ} 11^{\prime} 3.14^{\prime \prime}$ & 1993-2013 & VEN & 29 \\
\hline Caprile & 1008 & $46^{\circ} 26^{\prime} 25.35^{\prime \prime}$ & $11^{\circ} 59^{\prime} 24.13^{\prime \prime}$ & 1993-2013 & VEN & $22-40$ \\
\hline Corvara in Badia & 1558 & $46^{\circ} 33^{\prime} 1.48^{\prime \prime}$ & $11^{\circ} 52^{\prime} 23.71^{\prime \prime}$ & 1956-2013 & BUI & 26 \\
\hline Faloria & 2240 & $46^{\circ} 31^{\prime} 38.53^{\prime \prime}$ & $12^{\circ} 10^{\prime} 30.22^{\prime \prime}$ & 1993-2013 & VEN & $21-39-41$ \\
\hline Fié allo Sciliar & 840 & $46^{\circ} 30^{\prime} 48.24^{\prime \prime}$ & $11^{\circ} 30^{\prime} 21.60^{\prime \prime}$ & 1980-2013 & BUI & 37 \\
\hline Passo Falzarego & 2090 & $46^{\circ} 31^{\prime} 7.20^{\prime \prime}$ & $12^{\circ} 00^{\prime} 24.51^{\prime \prime}$ & 1993-2013 & VEN & $24-26-30$ \\
\hline Passo Rolle & 2012 & $46^{\circ} 17^{\prime} 52.70^{\prime \prime}$ & $11^{\circ} 47^{\prime} 13.10^{\prime \prime}$ & 1980-2013 & MET & $34-38$ \\
\hline Passo Costalunga & 1750 & $46^{\circ} 24^{\prime} 18.27^{\prime \prime}$ & $11^{\circ} 35^{\prime} 9.16^{\prime \prime}$ & 1991-2012 & MET & 20 \\
\hline Passo Monte Croce Comelico & 2150 & $44^{\circ} 41^{\prime} 21.99^{\prime \prime}$ & $07^{\circ} 07^{\prime} 42.93^{\prime \prime}$ & 1993-2013 & VEN & $25-32-33-35$ \\
\hline Passo Valles & 2032 & $46^{\circ} 20^{\prime} 18.20^{\prime \prime}$ & $11^{\circ} 47^{\prime} 59.20^{\prime \prime}$ & $1985-2013$ & MET & $36-37$ \\
\hline Sarentino & 966 & $46^{\circ} 38^{\prime} 26.16^{\prime \prime}$ & $11^{\circ} 21^{\prime} 18.36^{\prime \prime}$ & 1977-2013 & BUI & 23 \\
\hline Selva Gardena & 1570 & $46^{\circ} 32^{\prime} 44.16^{\prime \prime}$ & $11^{\circ} 46^{\prime} 6.24^{\prime \prime}$ & 1991-2013 & BUI & 36 \\
\hline Soffranco & 605 & $46^{\circ} 16^{\prime} 41.03^{\prime \prime}$ & $12^{\circ} 14^{\prime} 33.74^{\prime \prime}$ & 1993-2013 & VEN & 31 \\
\hline Solda & 1907 & $46^{\circ} 30^{\prime} 55.03^{\prime \prime}$ & $10^{\circ} 35^{\prime} 52.53^{\prime \prime}$ & 1971-2013 & BUI & $23-28$ \\
\hline Solda Cima Beltovo & 3328 & $46^{\circ} 30^{\prime} 10.37^{\prime \prime}$ & $10^{\circ} 37^{\prime} 42.91^{\prime \prime}$ & $1998-2013$ & BUI & 28 \\
\hline Villanova (Borca di Cadore) & 968 & $46^{\circ} 26^{\prime} 35.58^{\prime \prime}$ & $12^{\circ} 12^{\prime} 22.52^{\prime \prime}$ & 1993-2013 & VEN & 27 \\
\hline
\end{tabular}

three classes, i.e. $1500-2400,2400-3300$, and 3300$4200 \mathrm{~m}$ a.s.l. Rockfall volumes were ranked in two classes: rockfalls in the range $10^{2}-10^{4} \mathrm{~m}^{3}$ were classified as small events, and rockfalls in the range $10^{4}-$ $10^{6} \mathrm{~m}^{3}$ were considered large events. The probability of permafrost occurrence in the detachment zone was derived from the Alpine Permafrost Index Map (APIM) (Boeckli et al., 2012). APIM is defined as "a first resource to estimate permafrost conditions at any given location in the European Alps", and it represents a static snapshot of potential permafrost distribution. In rock, the maximal uncertainty in the elevation of the lower permafrost limit is estimated to be $\pm 360 \mathrm{~m}$. In this map, the likelihood of permafrost occurrence is classified in three classes: (i) permafrost "in nearly all conditions", (ii) "mostly in cold conditions", and (iii) "only in very favourable conditions", corresponding to a decreasing probability of permafrost occurrence. We have added the class "no permafrost" and we divided into four classes rockfall events with regard to the probability of permafrost occurrence in the detachment zone.

- Climate anomalies were grouped into five classes: (i) short-term (ST) temperature anomaly, i.e. positive and negative temperature anomaly at the daily and/or weekly scale; (ii) long-term (LT) temperature anomaly, i.e. positive and negative temperature anomaly at the monthly and/or quarterly scale; (iii) widespread (WT) temperature anomaly, i.e. temperature anomaly dis- 
tributed from the daily to the quarterly temporal range; (iv) precipitation anomaly (RT), i.e. precipitation anomaly from the weekly to the quarterly scale; and (v) no climate (NO) anomaly detected.

- A joint assessment of frequency distribution of climate anomalies in relation to spatiotemporal characteristics of rockfall events was performed.

\section{Results}

\subsection{Statistical analysis of climate variables}

Results of the analysis of the climate variables considered for this work are listed in Table 3. From this table, one can see that $34(83 \%)$ of 41 rockfalls considered in this work were associated with air temperature anomalies. For six rockfalls, a precipitation anomaly was detected, usually in combination with a temperature anomaly. The Brenva rockfall of 18 January 1997 is the only event in our catalogue that was associated solely to a precipitation anomaly. In six cases, the climate variables revealed no anomaly.

Temperature anomalies associated with rockfall occurrence were more frequently hot $(53 \%)$ than cold (35\%). In a few cases, both warm and cold temperature anomalies, at different temporal scales, were detected (12\%). ST temperature anomalies predominate (50\% of case studies) over LT anomalies (15\%), but in many cases WT anomalies were detected $(35 \%)$.

Of the six rockfall events associated with a precipitation anomaly, three events were associated only to a longterm precipitation anomaly, and three events were associated with precipitation anomalies both at the weekly and at the monthly/quarterly scale.

Regarding the regional distribution of our case studies, we notice that four of the six events with no detected anomaly occurred in the Eastern Italian Alps. In the Western Italian Alps, 11 out of 19 rockfall events $(58 \%)$ were associated with warm temperature anomalies (in the short-term and/or long-term range), whereas in the Eastern Italian Alps only nine out of 21 events $(43 \%)$ were associated with warm temperature anomalies. Conversely, only five out of 19 rockfalls $(26 \%)$ were associated with cold temperature anomalies in the Western Italian Alps, and eleven out of 21 events (52\%) in the Eastern Italian Alps. Finally, four of the six rockfall events associated with a precipitation anomaly were located in the Western Italian Alps.

\subsection{Spatial and temporal distribution of rockfalls}

The main characteristics of the spatial and temporal distributions of the considered events are listed in Table 1 and in Table A1 in the Appendix.. Looking at the elevation of the detachment areas, we note that the events are evenly distributed among all elevation classes. As regards the season of occurrence, the summer events predominate and occurred mostly at elevation higher than $2400 \mathrm{~m}$. All the spring events occurring at lower elevations, with the only exception of the Belvedere rockfall in April 2007. Both spring and summer events are equally distributed in the western and eastern sectors. Autumn events occurred mainly in the elevation range 2400-3300 m, and all have occurred in the Eastern Alps except for the Punta Tre Amici rockfall on September 2010. Winter rockfalls are the less numerous group, they occurred all between mid-December and mid-January, and most of them are located in the western sector of the study area.

While analysing the seasonal distribution of the events according to their volume, consider that information on the detached volume was available only for 26 rockfalls out of 41 $(63 \%)$. This is because the selected events often occurred in remote areas and caused no damage. It is likely that most of the processes for which we do not have this type of information are small-volume events $\left(>10^{4} \mathrm{~m}^{3}\right)$. Therefore, the number of small events is probably underestimated. Most of the small-volume events occurred during the summer and none in the winter. Conversely, the large-magnitude events show a quite homogeneous seasonal distribution. It is likely that the seasonal distribution of small events is influenced by the wider frequentation of mountain areas during the summer, which causes a higher probability of events and/or reporting. Finally, if we consider rockfall volumes vs. elevation, we notice that small-volume events concentrate in the lower- and intermediate-elevation classes, while large rockfalls occurred mainly above $2400 \mathrm{~m}$ a.s.l. The Val Formazza event of April 2009 is the only large event documented in the lower-elevation class. If we analyse the case studies according to the probability of permafrost occurrence in the detachment zone, we get an information similar to that provided by the terrain elevation: small-volume events occurred in non-permafrost areas or where permafrost is expected only in favourable conditions, while larger events mainly concentrate in areas where permafrost is expected in nearly all conditions.

\subsection{Climate anomalies and spatiotemporal distribution of rockfalls}

Results of the bivariate statistical analysis are shown in Fig. 3. The climate anomalies are grouped in the five types described in Sect. 4. Note that case studies showing both $R$ and $T$ anomalies were counted only once, in the RT group.

Results shown in Fig. 3a highlight that half of the spring and autumn events are associated with a ST anomaly. Summer events occurred mainly in the presence of ST or WT anomalies. ST anomalies are both warm and cold, while WT anomalies are always warm. Conversely, LT anomalies, which were found only on occasion of summer events, are cold and are at the quarterly range. Winter events are associated with ST (Sass Maor, December 2011) or WT (Rocciamelone II, December 2006) anomalies and/or with long- 


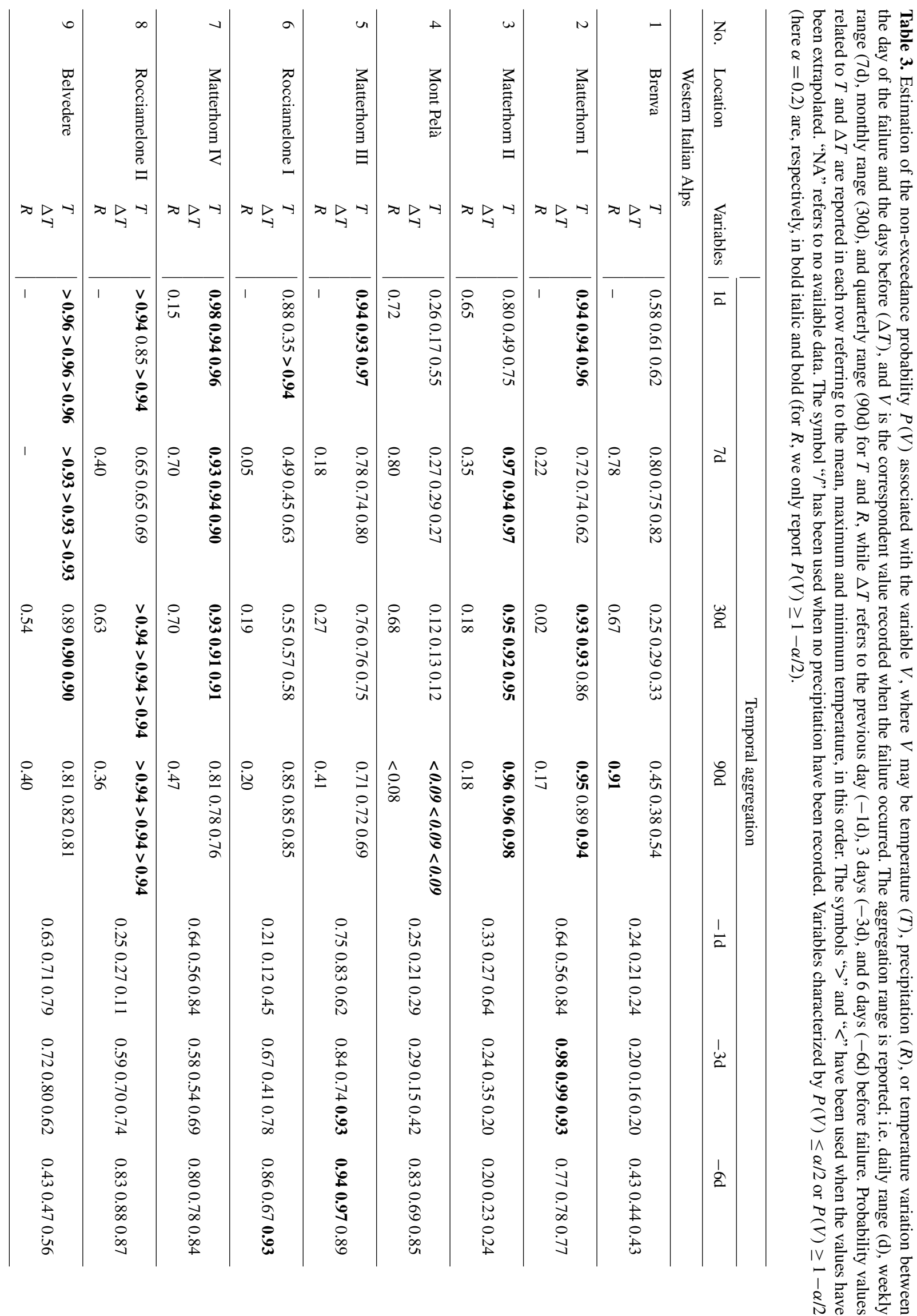




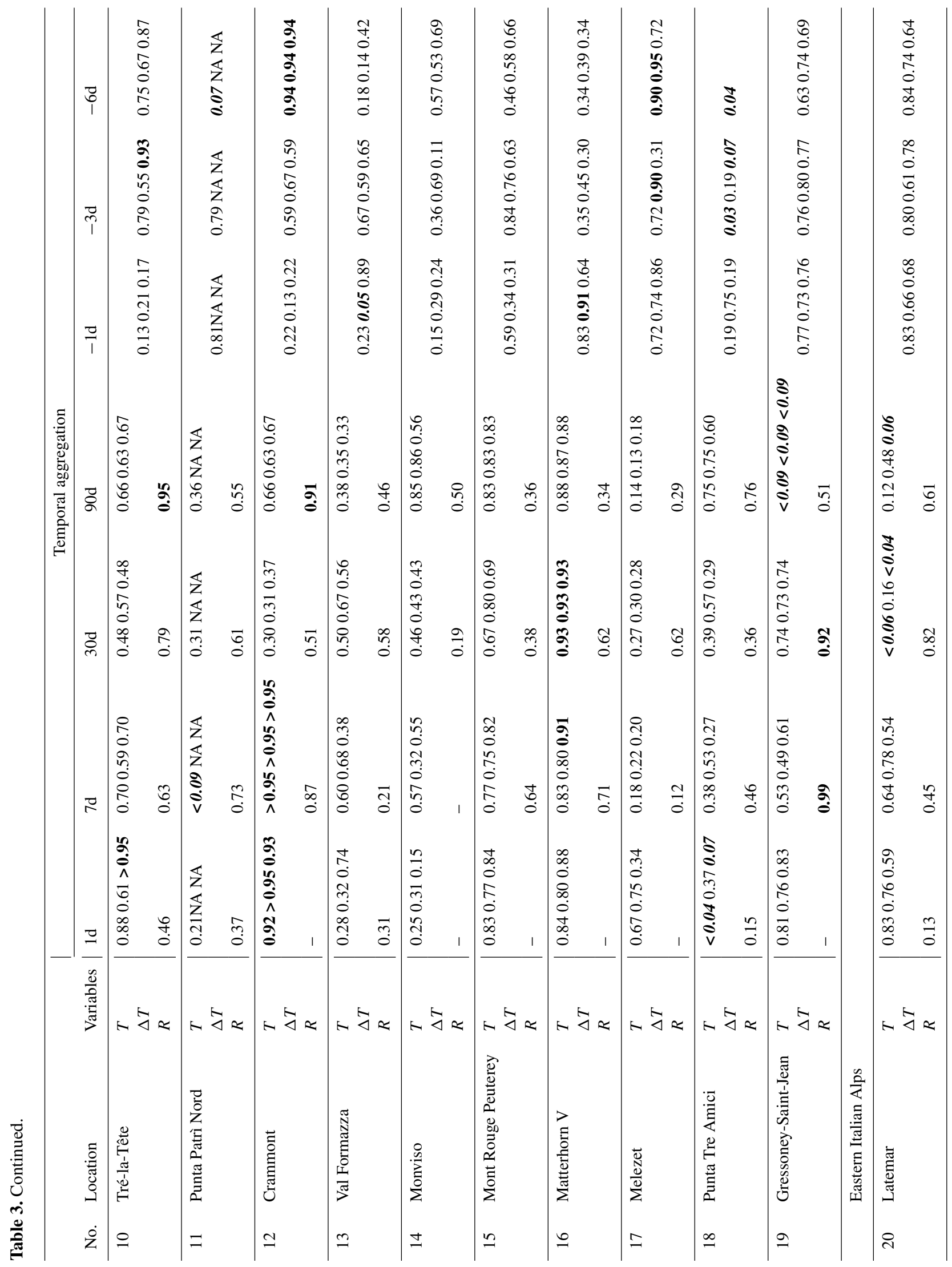




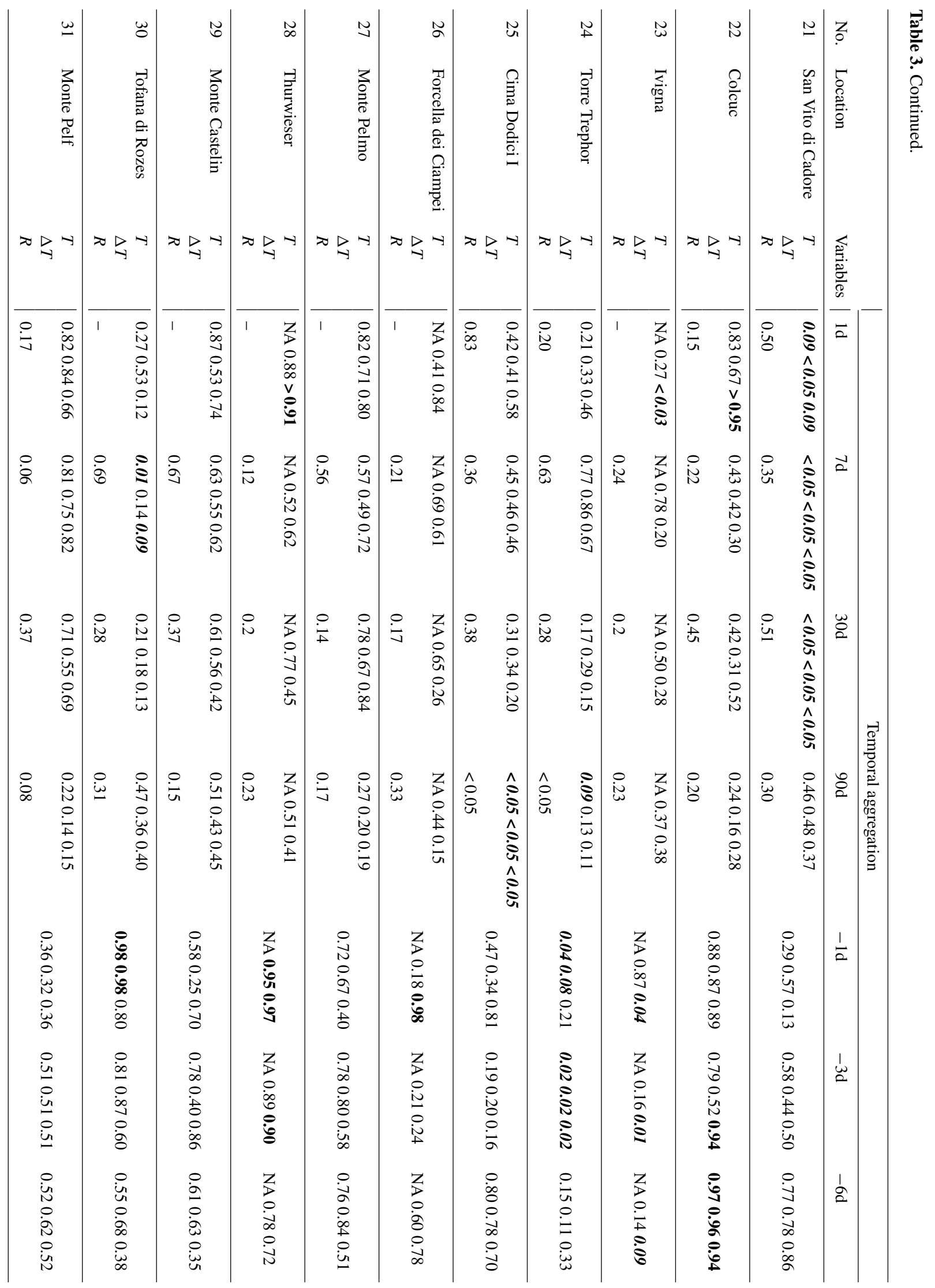




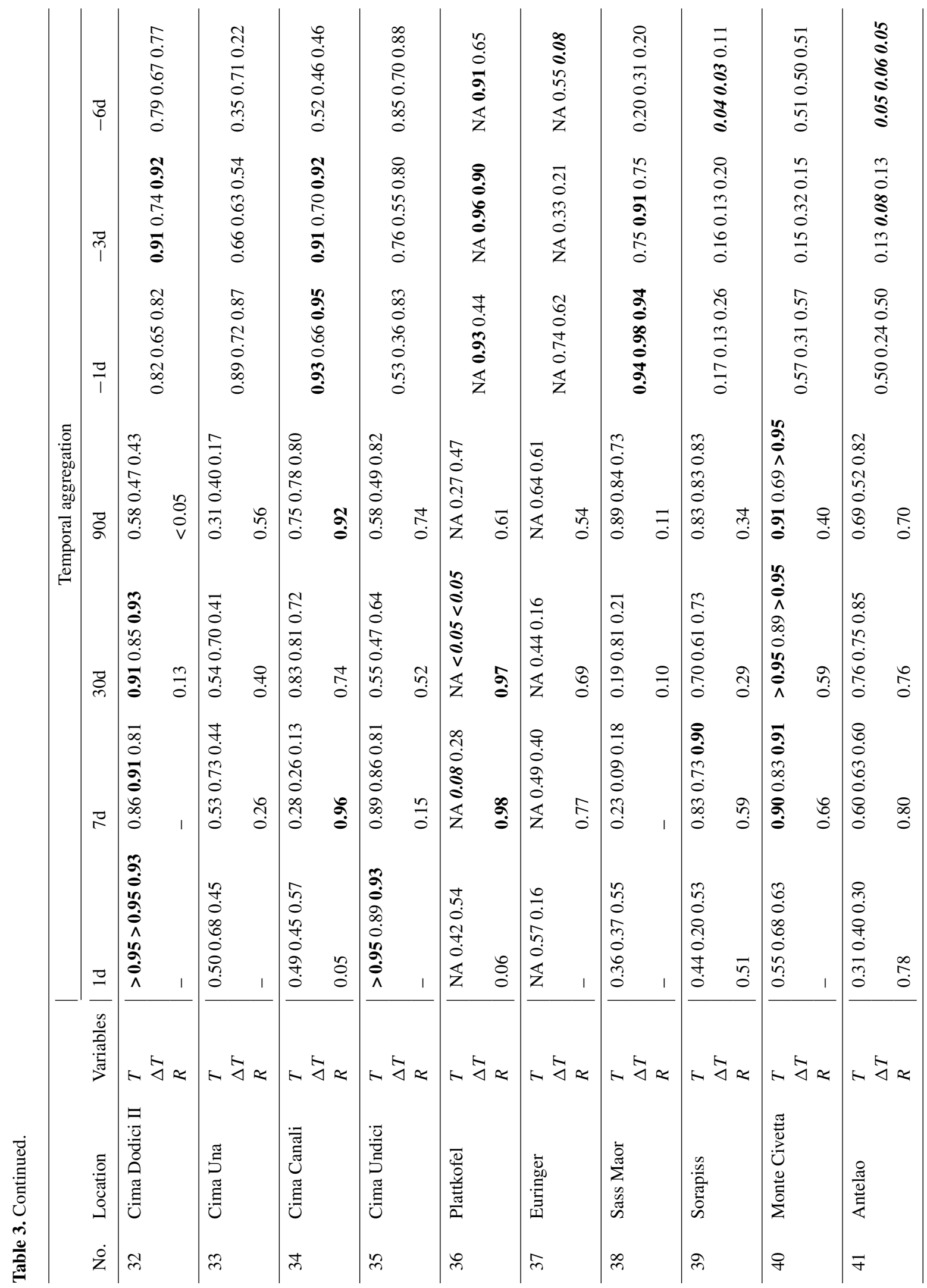



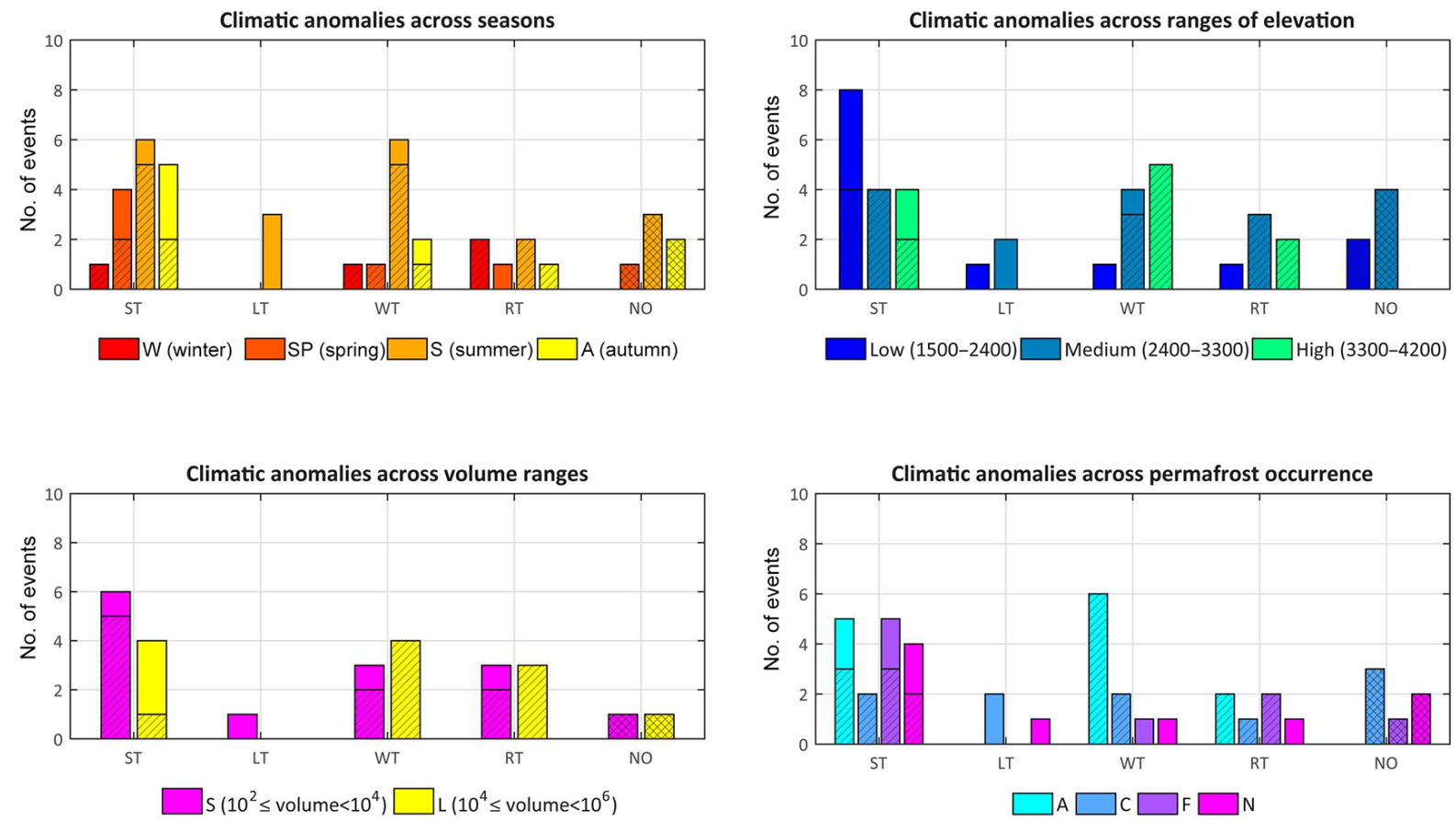

Figure 3. Distribution of rockfalls according to the type of climate anomaly, and considering (a) the season of occurrence, i.e. W (winter), SP (spring), S (summer), A (autumn); (b) the elevation, i.e. low (1500-2400 m), medium (2400-3300 m), high (3300-4200 m); (c) rockfall volume, i.e. small-volume events $\left(\mathrm{S}, 10^{2} \leq\right.$ volume $\left.<10^{4} \mathrm{~m}^{3}\right)$, large-volume events $\left(\mathrm{L}, 10^{4} \leq\right.$ volume $\left.<10^{6} \mathrm{~m}^{3}\right)$; (d) expected permafrost occurrence in the detachment zone, i.e. A (permafrost in nearly all conditions), $\mathrm{C}$ (mostly in cold conditions), $\mathrm{F}$ (only in very favourable conditions), N (no permafrost). Climate anomaly groups: ST is short-term temperature anomaly; LT is long-term temperature anomaly; WT is widespread temperature anomaly; $\mathrm{R}$ is precipitation anomaly (at the weekly range or longer) without or in association to temperature anomalies; NO indicates no anomaly. Warm T anomalies are highlighted with a striped overlay.

term $R$ anomalies (Brenva, January 1997; Crammont, December 2008).

Considering to the elevation of the rockfall detachment zone (Fig. 3b), low-elevation failures occurred mainly in combination with ST anomalies. Events occurred in the midrange class (2400-3300 ma.s.l.) are homogeneously distributed among all types of anomaly. However, they are also the most numerous group of events for which no anomaly was detected (four out of six events). Most of the events that occurring at the highest elevations are associated with ST or WT anomalies, with warm anomalies that significantly outweigh cold ones. Interestingly, none of the failures that occurred in the highest range of elevation is exclusively associated with long-term $T$ anomalies or with no anomaly.

With regard to the magnitude of the events (Fig. 3c), there is no strong indication of a preferential distribution of small and large events among the different climate anomalies, even though small events are more numerous in the ST group, while large events are quite evenly distributed among ST, WT, and RT groups.

As for the probability of occurrence of permafrost conditions in the detachment zone, Fig. 3d shows that eight events associated with WT anomalies occurred in areas where per- mafrost occurrence is likely. Conversely, in non-permafrost areas events mainly concentrate across ST anomalies.

Focusing on the type of climate anomaly, we can summarise the results illustrated in Fig. 3 as follows. ST anomalies (both warm and cold) are preferentially associated with small-volume failures, occurring in any season at lower elevations (where no permafrost is expected). Only a few events are associated uniquely with LT anomalies, which are always cold and at the quarterly range, and occurred during the summer. These events are located in the lower or medium range of elevation, where permafrost is absent or present only in cold conditions. WT anomalies (mainly of the warm type) are associated in particular to summer events, occurring at high elevation (in particular in the highest altitudes, where permafrost is present in all conditions) and that involve large volumes of rock. RT anomalies are associated with failures occurring in almost any season, of both small and large magnitude, mainly in the medium range of elevation, in variable permafrost conditions. Case studies associated with NO anomaly are mainly reported during the summer, at low or medium elevations. 


\section{Discussion}

In this work, we used a modified version of the statistical method proposed by Paranunzio et al. (2015), which can be easily applied to diverse climate and geographical settings and to any type of natural instability. This method provides a first screening of the climate parameters that might have contributed to slope failure occurrence. In this light, the most relevant outcomes of our analyses on a sample of 41 recent rockfalls in the Italian Alps can be synthesised as follows:

i. In $85 \%$ of our case studies, one (or more) climate anomaly was identified in association with rockfall occurrence.

ii. Most of the rockfall events were associated with a temperature anomaly (34 cases out of 41). In most cases (30 out of 34) it was a short-term temperature anomaly, occasionally (12 cases) combined with a long-term temperature anomaly.

iii. Surprisingly, temperature anomalies associated with rockfall occurrence were positive and/or negative, with only a slight prevalence of the positive anomalies.

iv. Only six rockfalls $(15 \%)$ were associated with exceptional precipitations in the medium/long term (i.e. 790 days before the failure).

v. Timing and conditions of rockfall initiation differ in relation to the elevation altitude. At lower elevation (1500-2400 m), rockfalls occurred mainly in spring and were mostly associated with negative temperature anomalies. At medium elevation (2400-3300 m), rockfall events concentrated in summer and positive temperature anomalies prevail with the negative anomalies. In this altitudinal range, we find the largest number of events not associated with climate anomaly. Summer events prevail also at the highest elevations $(>3300 \mathrm{~m})$, mostly in association with positive temperature anomalies.

vi. In the Western Alps, rockfalls associated with warm air temperatures predominate, whereas in the Eastern Alps rockfalls are often associated with very cold conditions.

At higher altitude (above $3300 \mathrm{~m}$ ) rockfalls documented since 2003 were mainly associated with positive temperature anomalies. Thus we can suppose that permafrost and cryosphere degradation induced by climate change could have a key role in the initiation of these events. At lower altitudes, the impact of climate change on slope stability, if it exists, must be sought in more complex processes (e.g. change of the snow/rain ratio, increased temperature variability with more frequent cycles of snowfall/snowmelt and of freeze/thaw in the rock slopes).

Looking to regional differences, the role of different lithology and topographic settings in the rockfall occurrence has to be considered analysing the results. As can be seen in Table 1 , most of the events occurred in gneisses and schists in the western sector, while dolomite is the prevalent lithology in the eastern one. We have to note that we refer to lithology maps at $1: 100000$ scale and, only when specific studies are available, a better level of detail could be provided. Thus, we had to adopt generalisations that could lead to a certain level of error considering that similar lithologies may be characterized by different geotechnical features (Fischer et al., 2012). However, this is not the focus of our study, since we concentrated on climate anomalies potentially leading to failure. Nevertheless, a more detailed study on the lithological and geomorphological features could be of help in the understanding of predisposing factors, which could be useful to explore in future studies.

Keeping in mind this point and considering the different elevation of occurrence of the listed rockfalls, we can suppose that slope failure occurrence in the Eastern Alps could be mainly attributed to water pressure increase inside the slopes; it may be related to freezing of water springs along the slopes and/or by repeated cycles of snowfall/snowmelt, especially in autumn. In the Western Alps, instead, slope failures could be ascribable to the build-up of water pressure in the rock masses due to accelerated snowmelt and/or permafrost thaw. The differences may be ascribed to the typical topographic settings of the two sectors as well. In particular, the Western Italian Alps host the highest peaks in the study area (e.g. Mont Blanc, 4810 m; Monte Rosa, 4637 m; Matterhorn $4478 \mathrm{~m}$ ), where we expect permafrost in all conditions. Peak elevation in the Eastern Alps is much lower (Tofana di Mezzo, 3245 m; Sorapiss, 3205 m; Cima Undici, 3092 m) and permafrost is expected only in cold or favourable conditions. Moreover, previous studies highlight that discontinuous permafrost could be found at different elevations, depending on the direction, i.e. at higher locations (around $3500 \mathrm{~m}$ a.s.l.) in southern aspects and at lower locations, from about $2500 \mathrm{~m}$ a.s.l., on NE-, N-, NW-, and W-facing slopes (Gruber et al., 2004; Fischer et al., 2012). This is in agreement with the fact that rockfalls in the Dolomites concentrate mostly on northern aspect (13 out 18 events in the eastern sector with available information on aspect), where permafrost could be found only in cold or favourable conditions.

By analysing the type of the detected climate anomaly (or anomalies) in combination with spatiotemporal characteristics of the individual rockfalls, we attempted to provide some possible explanation on the temperature-related processes that may have caused the slope failures. Details on this case-by-case analysis are listed in Table A1 in the Appendix, below we give general comments:

i. Permafrost thawing, necessarily related to a long-term (or wide-spread) positive temperature anomaly, seems to contribute to slope failure only at the highest elevations $(>3300 \mathrm{~m})$, and only as a predisposing factor. Our findings are in agreement with previous studies which 
pointed out that climatic variations over long-term period could destabilise greater depths of the rock mass (Gruber and Haeberli, 2007; Fischer et al., 2012). The linkage between processes at high-elevation sites and permafrost degradation has already been highlighted by several authors, who have reconstructed and described the events included in our catalogue, e.g. Matterhorn events (Deline et al., 2011) and Belvedere and Punta Tre Amici events (Fischer et al., 2013).

ii. Positive ST anomalies may have contributed to rockfall triggering in multiple ways. In spring and early summer, they may have increased the snow cover melting (Cardinali et al., 2000; Saez et al., 2013). In summer, they may have enhanced the ongoing process of active-layer thickening (Gruber et al., 2004; Gruber and Haeberli, 2007; Harris et al., 2009). In autumn, warm temperatures may have caused melting of an early snowfall or precipitation to fall as rain rather than as snow. In particular, infiltration of water into the bedrock fractures due to rainfall or particularly when near-surface ice/snow is available for melt (because of rain-on-snow process or high temperatures melting early snowfall) may reduce the shear strength of the rock mass potentially leading to the failure (Fischer et al., 2010; Allen and Huggel, 2013).

iii. More complex is the interpretation of the role of the positive ST and WT anomalies that are usually associated with winter events. In these cases, it is likely that temperature, though higher than the average, was well below $0{ }^{\circ} \mathrm{C}$ at the time of failure.

iv. Negative ST anomalies may have been responsible for rockfall triggering by freezing the water springs along the slope, thus causing the blockage of groundwater flow and the build-up of water pressure in the rock masses leading to slope failure (Govi et al., 1993; Fischer et al., 2013; McSaveney and Massey, 2013).

v. Small-volume events are supposed to be more influenced by near-surface dynamics, related to a faster response to climatic variables variations. However, largevolume events involve greater depths, as a consequence of complex and gradual processes, mainly linked to longer-term climatic anomalies (Allen and Huggel, 2013).

In order to properly consider the outcomes of this study, some important constraints of our work have to be kept in mind. Our method may not have detected all possible climate anomalies associated with the onset of the slope failures. To refine the results, or to use the method for different purposes or in different geographic settings, the method can be composed and/or integrated with further variables and analysis, e.g. considering different temporal aggregations scales.
Our method is not an operational tool for landslide (rockfall) forecasting; i.e. it does not provide thresholds for rockfall initiation. In order to do so, it would need to be further validated on a larger dataset and with a false positive analysis, i.e. the analysis of the number of times that a climate anomaly was detected and no slope instability occurred. However, this validation could prove difficult for high-elevation areas, where slope failures are only seldom reported. Our method is instead intended as a tool for assessing the possible role of climate parameters in slope failure occurrence. We are aware that the number of rockfalls included in our catalogue is limited from a statistical point of view. In this light, since our main requirements while collecting data for our study were the knowledge of the failure date and of the (at least indicative) location of the detachment zone, together with the availability of climate records covering the failure date, only part of the rockfall events that we collected could be used for this work. Moreover, we have to keep in mind that inhomogeneities related to data acquisition timing and relevance of the event exist (e.g. summer events are more documented due to tourism increase in summer months as well as large-volume events). Finally, many news come from newspapers and may contain inaccuracies, which are not always simple to identify and connect.

However, we point out that only a few inventories of this type are available in the literature, and their size and systematic nature are comparable to that of our dataset (Noetzli et al., 2003; Ravanel et al., 2010; Allen et al., 2011; Fischer et al., 2012; Allen and Huggel, 2013). We have concentrated on those events that, based on the available documentation, occurred in the absence of evident rainfall, in order to assess if temperature (and climate warming) could be a key factor at high-elevation sites, where the cryosphere plays a major role in geomorphological dynamics, including slope failures. Data collected in the inventories are the result of years of documentation, field surveys, and remote sensing. It is unlikely that the number of events listed in the catalogue will increase substantially in the next few years, considering the remoteness and the low frequentation of high mountains, unless new techniques will become available to support this type of studies (e.g. Manconi et al., 2016). The straightest way to overcome these difficulties would be the combination of datasets from different mountain areas of the world. This approach would give more strength and robustness to the statistical analysis, even if one will always inevitably cope with small numbers of case studies, compared to other types of processes or other geographic settings. Moreover, merging catalogues from different sources would require that the collection of geologic and climate data be done according to common standards. Gridded data could be of help in overcoming inconsistencies in the lack of climate data, but the spatial and temporal resolution of the dataset has to be considered, since usually they include data with a large geographic extension and on a long term. Certainly, the creation of shared dataset at European scale would be a crucial and ex- 
citing point to be addressed in the future, but it has to be done through the direct involvement of the scientists who worked on such data and not simply combining different inventories. This is not the case at the moment, despite a few attempts in this direction conducted in the framework of international projects (e.g. Deline et al., 2007).

\section{Conclusions}

The statistical method used in this work proved to be a valuable tool to discriminate whether, and which, climate variables may have contributed to rockfall initiation at high elevation in recent years. The schematic nature and the simplicity of the method are, in our view, also its main strength, as the method can be applied to a wide range of climate parameters, to any process of instability, and in any geographical context. In this paper, we focus on the time of occurrence of rockfalls (i.e. "when") rather than on the spatial characterisation of the failure area (i.e. "where"). This is not a case-by-case study, and thus the interpretation of failure mechanisms and/or the geological/structural characterisation of the detachment areas go beyond the purposes of this work. We rather aim to catch a possible climatic signal at different timescales, which could be related to rockfall triggering.

Our results show that, in absence of a clear rainfall trigger, temperature is a key factor controlling rockfall occurrence in the Italian Alps. The considerable number of events associated with cold anomalies would suggest that the role of global warming is not so evident, but it offers interesting insights in the study of the linkage between climate variables and landslide initiation. Our study also demonstrates that the type of temperature anomaly, and thus how temperature controlled rockfall occurrence, was very different from case to case. Warm temperatures could enhance permafrost thaw and snowmelt at higher altitudes or cause melting of early snowfall at lower elevation. Cold temperature anomalies may cause the blockage of groundwater flow and the build-up of high water pressures inside the rock mass. Some interesting insights could be made on the spatial distribution of the anomalies: rockfalls in the Eastern Alps are mainly related to cold temperature anomalies, while in the Western Alps slope failures are mainly associated with warm temperature anomalies.

In conclusion, the approach used in this study allowed to define the climate signature of the considered slope failures. Our paper represents only a preliminary work in this direction and suggests an approach that can help discriminating those processes that may be somehow related with climate change, from those that appear unrelated. A bottom-up assessment of the role of climate variables in the development of a set of slope failure events, as we did in this work, is an essential step towards a characterisation and quantification of the impacts of climate change on slope instability in mountain areas and towards a definition of hazard scenarios under the present climate trend.

\section{Data availability}

For further information regarding the data used in this paper, please contact the authors directly. 


\section{Appendix A}

Table A1. Synthetic characterisation of case studies and possible processes leading to slope failure. Number (no.) and location of case studies are the same as in Table 1. Climate anomaly is the type of anomaly associated with rockfall occurrence: ST is short-term temperature anomaly; LT is long-term temperature anomaly; WT is widespread temperature anomaly; RT is precipitation anomaly - at the weekly range or longer - without or in association to temperature anomalies; NO indicates no anomaly. Positive temperature anomaly $(P(V) \geq 1-\alpha / 2)$ is indicated as + while negative temperature anomaly $(P(V) \leq \alpha / 2)$ is indicated as - . The coexistence of both anomalies is indicated as \pm . Season is the season of occurrence of rockfalls: W (winter), SP (spring), S (summer), A (autumn). Elevation is the range of elevation $z$ of rockfall niche (ma.s.1.): $\mathrm{L}(1500 \leq z<2400)$, M $(2400 \leq z<3300), \mathrm{H}(3300 \leq z \leq 4200)$. Volume is the volume of detached rock $\left(\mathrm{m}^{3}\right)$ : small-volume $\left(\mathrm{S}, 10^{2} \leq\right.$ volume $\left.<10^{4}\right)$ and large-volume $\left(\mathrm{L}, 10^{4} \leq\right.$ volume $\left.<10^{6}\right)$ events. Permafrost is the expected permafrost occurrence in the detachment zone: A (permafrost in nearly all conditions), $\mathrm{C}$ (mostly in cold conditions), $\mathrm{F}$ (only in very favourable conditions), $\mathrm{N}$ (no permafrost).

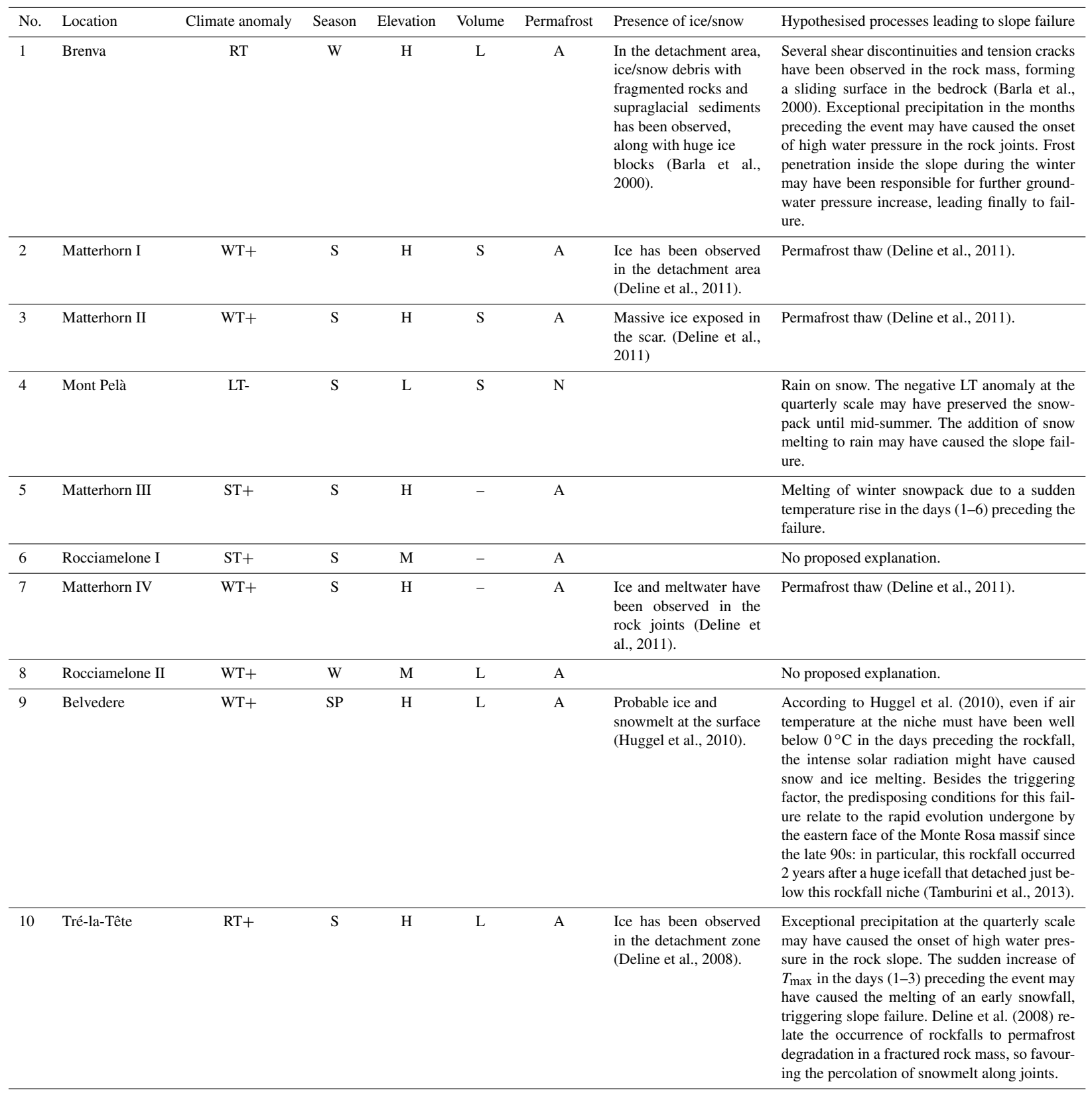


Table A1. Continued.

\begin{tabular}{|c|c|c|c|c|c|c|c|c|}
\hline No. & Location & Climate anomaly & Season & Elevation & Volume & Permafrost & Presence of ice/snow & Hypothesised processes leading to slope failure \\
\hline 11 & Punta Patrì Nord & ST- & $\mathrm{S}$ & $\mathrm{H}$ & $\mathrm{L}$ & A & $\begin{array}{l}\text { Meltwater coming } \\
\text { from ice lens uncovered } \\
\text { by the rockfall has been } \\
\text { observed (Deline et al., } \\
\text { 2011). }\end{array}$ & $\begin{array}{l}\text { Freezing of water springs along the slope, } \\
\text { blocking the seepage of water from the per- } \\
\text { mafrost thaw through the rock mass: the build- } \\
\text { up of high water pressure may have caused the } \\
\text { collapse of the rock mass. }\end{array}$ \\
\hline 12 & Crammont & $\mathrm{RT}+$ & W & M & $\mathrm{L}$ & $\mathrm{F}$ & $\begin{array}{l}\text { Snow was present (De- } \\
\text { line et al., 2011). }\end{array}$ & $\begin{array}{l}\text { No proposed explanation about the event trig- } \\
\text { ger. Deline et al. (2013) relate the occurrence } \\
\text { of this rockfall to permafrost degradation, based } \\
\text { on the presence of seepage water in the scar af- } \\
\text { ter the collapse, in spite of negative air temper- } \\
\text { atures. }\end{array}$ \\
\hline 13 & Val Formazza & ST- & SP & $\mathrm{L}$ & $\mathrm{L}$ & $\mathrm{N}$ & & $\begin{array}{l}\text { Freezing of water springs along the slope and } \\
\text { consequent blockage of snowmelt water seep- } \\
\text { age through the rock mass: the high water pres- } \\
\text { sure caused by the blockage of the water flow } \\
\text { may have caused the collapse of the rock mass. }\end{array}$ \\
\hline 14 & Monviso & NO & $\mathrm{S}$ & M & $\mathrm{S}$ & $\mathrm{C}$ & & No detected anomaly. \\
\hline 15 & Mont Rouge Peuterey & NO & $\mathrm{S}$ & M & - & $\mathrm{F}$ & & No detected anomaly. \\
\hline 16 & Matterhorn V & WT + & $S$ & $\mathrm{H}$ & - & A & & Permafrost thaw. \\
\hline 17 & Melezet & $\mathrm{ST}+$ & SP & $\mathrm{L}$ & $\mathrm{S}$ & $\mathrm{N}$ & & $\begin{array}{l}\text { Accelerated snow melt due to sudden tempera- } \\
\text { ture increase. }\end{array}$ \\
\hline 18 & Punta Tre Amici & $\mathrm{ST}-$ & A & $\mathrm{H}$ & $\mathrm{L}$ & A & & $\begin{array}{l}\text { Freezing of water springs along the slope, } \\
\text { blocking the seepage of water from the per- } \\
\text { mafrost thaw through the rock mass: the build- } \\
\text { up of high water pressure may have caused the } \\
\text { collapse of the rock mass (Fischer et al., 2013). }\end{array}$ \\
\hline 19 & Gressoney-Saint-Jean & RT- & SP & $\mathrm{L}$ & $\mathrm{S}$ & $\mathrm{N}$ & & $\begin{array}{l}\text { Snow melt of an exceptionally deep snow pack. } \\
\text { The amount of water released by snowmelt may } \\
\text { have been particularly relevant because of the } \\
\text { combination of a cold temperature anomaly at } \\
\text { the quarterly scale with extraordinary precipita- } \\
\text { tions in the month before the event, resulting in } \\
\text { a deep snowpack. }\end{array}$ \\
\hline 20 & Latemar & LT- & $S$ & M & - & $\mathrm{C}$ & & $\begin{array}{l}\text { Snow melt of an exceptionally deep snow pack. } \\
\text { The amount of water released by snowmelt may } \\
\text { have been particularly relevant because of the } \\
\text { combination of a cold temperature anomaly at } \\
\text { the quarterly scale with extraordinary precipita- } \\
\text { tions in the month before the event, resulting in } \\
\text { a deep snowpack. }\end{array}$ \\
\hline 21 & San Vito di Cadore & WT- & A & M & $S$ & $\mathrm{~F}$ & & $\begin{array}{l}\text { Freezing of water springs along the slope and } \\
\text { consequent blockage of water seepage through } \\
\text { the rock mass: the high water pressure caused } \\
\text { by the blockage of the water flow may have } \\
\text { caused the collapse of the rock mass. }\end{array}$ \\
\hline 22 & Colcuc & $\mathrm{ST}+$ & SP & $\mathrm{L}$ & S & $\mathrm{N}$ & & $\begin{array}{l}\text { Accelerated snow melt due to sudden tempera- } \\
\text { ture increase. }\end{array}$ \\
\hline 23 & Ivigna & $\mathrm{ST}-$ & SP & $\mathrm{L}$ & - & $\mathrm{N}$ & & $\begin{array}{l}\text { Freezing of water springs along the slope and } \\
\text { consequent blockage of snowmelt water seep- } \\
\text { age through the rock mass: the high water pres- } \\
\text { sure caused by the blockage of the water flow } \\
\text { may have caused the collapse of the rock mass. }\end{array}$ \\
\hline 24 & Torre Trephor & WT- & SP & $\mathrm{L}$ & - & $\mathrm{N}$ & & $\begin{array}{l}\text { Freezing of water springs along the slope and } \\
\text { consequent blockage of snowmelt water seep- } \\
\text { age through the rock mass: the high water pres- } \\
\text { sure caused by the blockage of the water flow } \\
\text { may have caused the collapse of the rock mass. }\end{array}$ \\
\hline
\end{tabular}


Table A1. Continued.

\begin{tabular}{|c|c|c|c|c|c|c|c|c|}
\hline No. & Location & Climate anomaly & Season & Elevation & Volume & Permafrost & Presence of ice/snow & Hypothesised processes leading to slope failure \\
\hline 25 & Cima Dodici I & LT- & $S$ & M & - & $\mathrm{C}$ & & $\begin{array}{l}\text { Rain on snow. The negative LT anomaly at the } \\
\text { quarterly scale may have preserved. the snow- } \\
\text { pack until the date of the event. The addition of } \\
\text { snow melting to rain may have caused the slope } \\
\text { to fail. }\end{array}$ \\
\hline
\end{tabular}

\begin{tabular}{llllllll}
\hline 26 & Forcella dei Ciampei & ST + & S & L & S & N & \\
\hline 27 & Monte Pelmo & NO & S & M & - & C & \\
\hline 28 & Thurwieser & ST + & S & H & L & A & $\begin{array}{l}\text { Few ice blocks have } \\
\text { been found in the debris } \\
\text { (Sosio et al., 2008). }\end{array}$
\end{tabular}

Accelerated snowmelt due to sudden temperature increase the day of the event.

\begin{tabular}{llcccc}
\hline 29 & Monte Castelin & NO & A & L & - \\
\hline 30 & Tofana di Rozes & ST \pm & S & M & -
\end{tabular}

No detected anomaly.

Accelerated permafrost thaw due to sudden temperature increase in the days (1-3) preceding the event.

No detected anomaly.

Rapid melting of an early snowfall. Temperature suddenly raised in the day of the event, following extraordinarily low temperatures and heavy precipitation in the week before the event.

\begin{tabular}{llllllll}
\hline 31 & Monte Pelf & NO & SP & L & - & N & \\
\hline 32 & Cima Dodici II & WT & S & M & L & C & \\
\hline 33 & Cima Una & NO & A & M & L & C & $\begin{array}{l}\text { Any ice or water on } \\
\text { the failure surface have } \\
\text { been observed (Viero et } \\
\text { al., 2013). }\end{array}$ \\
\hline 34 & Cima Canali & RT + & S & M & S & F &
\end{tabular}

No detected anomaly.

Rapid snowmelt caused by extraordinarily high temperatures in the month and in the days preceding the event.

No detected anomaly.

S $\quad$ M $\quad S$

Heavy precipitations in the week and in the months preceding the event. No proposed explanation for the trigger.

\begin{tabular}{llllllll}
\hline 35 & Cima Undici & ST+ & S & M & S & C & \\
\hline 36 & Plattkofel & RT \pm & S & M & S & C & $\begin{array}{l}\text { The break off surface } \\
\text { was partially covered } \\
\text { by an ice-debris mix- } \\
\text { ture (Deline et al., } \\
\text { 2011) }\end{array}$ \\
\hline 37 & Euringer & ST- & S & L & S & F &
\end{tabular}

No proposed explanation.

Rapid melting of an early snowfall. Temperature suddenly raised the day of the event, following extraordinarily low temperatures and heavy precipitation in the month before the event.

Freezing of water springs along the slope and consequent blockage of snowmelt water seepage through the rock mass: the high water pressure caused by the blockage of the water flow may have caused the collapse of the rock mass.

\begin{tabular}{|c|c|c|c|c|c|c|c|}
\hline 38 & Sass Maor & $\mathrm{ST} \pm$ & $\mathrm{W}$ & $\mathrm{L}$ & - & $\mathrm{F}$ & No proposed explanation. \\
\hline 39 & Sorapiss & $\mathrm{ST} \pm$ & A & M & $\mathrm{S}$ & $\mathrm{C}$ & $\begin{array}{l}\text { Freezing of water springs along the slope and } \\
\text { consequent blockage of water seepage through } \\
\text { the rock mass: the high water pressure caused } \\
\text { by the blocking of the water flow may have } \\
\text { caused the collapse of the rock mass. }\end{array}$ \\
\hline 40 & Monte Civetta & WT+ & $\mathrm{A}$ & M & $\mathrm{L}$ & $\mathrm{C}$ & $\begin{array}{l}\text { Warm temperatures allowed precipitations to } \\
\text { fall as rain rather than as snow in the week and } \\
\text { month before the event. }\end{array}$ \\
\hline 41 & Antelao & $\mathrm{ST}-$ & A & $\mathrm{L}$ & - & $\mathrm{F}$ & $\begin{array}{l}\text { Freezing of water springs along the slope and } \\
\text { consequent blockage of water seepage through } \\
\text { the rock mass: the high water pressure caused } \\
\text { by the blocking of the water flow may have } \\
\text { caused the collapse of the rock mass. }\end{array}$ \\
\hline
\end{tabular}


Acknowledgements. This research was conducted with funding provided by the Italian National Department for Civil Protection (DPC) in the framework of a CNR IRPI project. F. Laio and R. Paranunzio acknowledge support from the ERC project CoG 647473. We thank ARPA Piemonte, ARPA Lombardia, ARPA Veneto, Centro Funzionale - Regione Autonoma Valle d'Aosta, Ufficio Idrografico - Provincia Autonoma di Bolzano, and Meteotrentino for providing access to their climate databases.

Edited by: O. Katz

Reviewed by: S. Allen and one anonymous referee

\section{References}

Allen, S. and Huggel, C.: Extremely warm temperatures as a potential cause of recent high mountain rockfall, Global Planet. Change, 107, 59-69, 2013.

Allen, S. K., Cox, S. C., and Owens, I. F.: Rock avalanches and other landslides in the central Southern Alps of New Zealand: a regional study considering possible climate change impacts, Landslides, 8, 33-48, 2011.

ARPA Piemonte: Evento meteopluviometrico del 26-28 aprile 2009, 2009.

Auer, I., Bohm, R., Jurkovic, A., Lipa, W., Orlik, A., Potzmann, R., Schoner, W., Ungersbock, M., Matulla, C., Briffa, K., Jones, P., Efthymiadis, D., Brunetti, M., Nanni, T., Maugeri, M., Mercalli, L., Mestre, O., Moisselin, J. M., Begert, M., Muller-Westermeier, G., Kveton, V., Bochnicek, O., Stastny, P., Lapin, M., Szalai, S., Szentimrey, T., Cegnar, T., Dolinar, M., Gajic-Capka, M., Zaninovic, K., Majstorovic, Z., and Nieplova, E.: HISTALP - historical instrumental climatological surface time series of the Greater Alpine Region, Int. J. Climatol., 27, 17-46, 2007.

Barla, G., Dutto, F., and Mortara, G.: Brenva glacier rock avalanche of 18 January 1997 on the Mount Blanc range, northwest Italy, Landslide News, 13, 2-5, 2000.

Beniston, M.: Mountain weather and climate: A general overview and a focus on climatic change in the Alps, Hydrobiologia, 562, 3-16, 2006.

Boeckli, L., Brenning, A., Gruber, S., and Noetzli, J.: Permafrost distribution in the European Alps: calculation and evaluation of an index map and summary statistics, The Cryosphere, 6, 807820, doi:10.5194/tc-6-807-2012, 2012.

Brunetti, M., Lentini, G., Maugeri, M., Nanni, T., Auer, I., Bohm, R., and Schoner, W.: Climate variability and change in the Greater Alpine Region over the last two centuries based on multivariable analysis, Int. J. Climatol., 29, 2197-2225, 2009.

Brunetti, M. T., Peruccacci, S., Antronico, L., Bartolini, D., Deganutti, A. M., Gariano, S. L., Iovine, G., Luciani, S., Luino, F., Melillo, M., Palladino, M. R., Parise, M., Rossi, M., Turconi, L., Vennari, C., Vessia, G., Viero, A., and Guzzetti F.: Catalogue of Rainfall Events with Shallow Landslides and New Rainfall Thresholds in Italy, in: Engineering Geology for Society and Territory-Volume 2, Springer International Publishing, Switzerland, 1575-1579, 2015.

Cardinali, M., Ardizzone, F., Galli, M., Guzzetti, F., and Reichenbach, P.: Landslides triggered by rapid snow melting: the December 1996-January 1997 event in Central Italy, in: Proceedings 1st
Plinius Conference on Mediterranean Storms, Maratea, Italy, 1416 October 1999, 439-448, 2000.

Chiarle, M. and Mortara, G.: Geomorphological impact of climate change on alpine glacial and periglacialareas. Examples of processes and description of research needs, in: Interpraevent 2008 conference proceedings, Dornbirn, Austria, 26-30 May 2008, vol 2, 111-122, 2008.

Chiarle, M., Paranunzio, R., Laio, F., Nigrelli, G., and Guzzetti, F.: Recent slope failures in the Dolomites (Northeastern Italian Alps) in a context of climate change, EGU General Assembly, Vienna, Austria, 27 April-2 May, EGU2014-4017, 2014.

Davies, M. C., Hamza, O., and Harris, C.: The effect of rise in mean annual temperature on the stability of rock slopes containing icefilled discontinuities, Permafrost Periglac., 12, 137-144, 2001.

Deline, P., Arattano, M., Chiarle, M., Cremonese, E., Giardino, M., Giulietto, W., Gruber, S., Jaillet, S., Morra di Cella, U., Mortara, G., Noetzli, J., Pau, R., Ravanel, L., Rabatel, A., Pogliotti, P., Ravello, M., Tamburini, A., Vagliasindi, M., and Voyat, I.: The relation of permafrost degradation and slope instabilities in highAlpine steep rockwalls (Mont Blanc massif and Matterhorn): the research project PERMAdataROC, EGU General Assembly, Vienna, Austria, 15-20 April 2007, EGU2007-A-07191, 2007.

Deline, P., Kirkbride, M. P., Ravanel, L., and Ravello, M.: The Tréla-Tête rockfall onto the Lex Blanche Glacier, Mont Blanc Massif, Italy, in September 2008, Geogr. Fis. Din. Quat., 31, 251254, 2008.

Deline, P., Chiarle, M., Curtaz, M., Kellerer-Pirklbauer, A., Lieb, G. K., Mayr, V., Mortara, G., and Ravanel L.: Chapter 3: Rockfalls, in: Hazards related to permafrost and to permafrost degradation, PermaNET project, state-of-the-art report 6.2, edited by: Schoeneich, P., Dall'Amico, M., Deline, P., and Zischg, A., online publication ISBN 978-2-903095-59-8, 67-105, 2011.

Deline, P., Broccolato, M., Noetzli, J., Ravanel, L., and Tamburini, A.: The December 2008 Crammont Rock avalanche, Mont Blanc Massif Area, Italy, in: Landslide Science and Practice, Global Environ. Change, 4, 403-408, 2013.

Esposito, S., Alilla, R., Beltrano, M. C., Dal Monte, G., Di Giuseppe, E., Iafrate, L., Libertà, A., Parisse, B., Raparelli, E., and Scaglione, M.: Atlante italiano del clima e dei cambiamenti climatici, Progetto Agroscenari, Consiglio per la Ricerca e la Sperimentazione in Agricoltura, Unità di Ricerca per la Climatologia e la Meteorologia applicate all'Agricoltura, 29-30 October 2014, Rome, Italy, 2014.

Fischer, L., Amann, F., Moore, J. R., and Huggel, C.: Assessment of periglacial slope stability for the 1988 Tschierva rock avalanche (Piz Morteratsch, Switzerland), Eng. Geol., 116, 32-43, 2010.

Fischer, L., Purves, R. S., Huggel, C., Noetzli, J., and Haeberli, W.: On the influence of topographic, geological and cryospheric factors on rock avalanches and rockfalls in high-mountain areas, Nat. Hazards Earth Syst. Sci., 12, 241-254, doi:10.5194/nhess12-241-2012, 2012.

Fischer, L., Huggel, C., Kääb, A., and Haeberli, W.: Slope failures and erosion rates on a glacierized high-mountain face under climatic changes, Earth Surf. Proc. Land., 38, 836-846, 2013.

Fitzsimons, S. J. and Veit, H.: Geology and geomorphology of the European Alps and the Southern Alps of New Zealand: A comparison, Mt. Res. Dev., 21, 340-349, 2001. 
Govi, M., Pasuto, A., Silvano, S., and Siorpaes, C.: An example of a low-temperature-triggered landslide, Eng. Geol., 36, 53-65, 1993.

Gruber, S. and Haeberli, W.: Permafrost in steep bedrock slopes and its temperatures-related destabilization following climate change, J. Geophys. Res.-Earth, 112, F02S18, doi:10.1029/2006JF000547, 2007.

Gruber, S., Hoelzle, M., and Haeberli, W.: Permafrost thaw and destabilization of Alpine rock walls in the hot summer of 2003, Geophys. Res. Lett., 31, L13504, doi:10.1029/2004g1020051, 2004

Guzzetti, F., Peruccacci, S., Rossi, M., and Stark, C. P.: The rainfall intensity-duration control of shallow landslides and debris flows: An update, Landslides, 5, 3-17, doi:10.1007/s10346-007-0112$1,2008$.

Harris, C., Arenson, L. U., Christiansen, H. H., Etzemuller, B., Frauenfelder, R., Gruber, S., Haeberli, W., Hauck, C., Holzle, M., Humlum, O., Isaksen, K., Kaab, A., Kern-Lutschg, M. A., Lehning, M., Matsuoka, N., Murton, J. B., Nozli, J., Phillips, M., Ross, N., Seppala, M., Springman, S. M., and Muhll, D. V: Permafrost and climate in Europe: Monitoring and modelling thermal, geomorphological and geotechnical responses, Earth-Sci. Rev., 92, 117-171, doi:10.1016/j.earscirev.2008.12.002, 2009.

Huggel, C., Salzmann, N., Allen, S., Caplan-Auerbach, J., Fischer, L., Haeberli, W., Larsen, C., Schneider, D., and Wessels, R.: Recent and future warm extreme events and highmountain slope stability, Philos. T. Roy. Soc. A, 368, 2435-2459, doi:10.1098/rsta.2010.0078, 2010.

Kääb, A., Chiarle, M., Raup, B., and Schneider, C.: Climate change impacts on mountain glaciers and permafrost, Global Planet. Change, 56, vii-ix, doi:10.1016/j.gloplacha.2006.07.008, 2007.

Manconi, A., Picozzi, M., Coviello, V., De Santis, F., and Elia, L.: Real-time detection, location, and characterization of rockslides using broadband regional seismic networks, Geophys. Res. Lett., 43, 6960-6967, doi:10.1002/2016GL069572, 2016.

McSaveney, M. and Massey, C.: Did radiative cooling trigger New Zealand's 2007 Young River landslide?, in: Landslide Science and Practice, edited by: Margottini, C., Canuti, P., and Sassa, K., Springer Berlin Heidelberg, Germany, G347-353, 2013.

Nigrelli, G., Lucchesi, S., Bertotto, S., Fioraso, G., and Chiarle, M.: Climate variability and Alpine glaciers evolution in Northwestern Italy from the Little Ice Age to the 2010s, Theor. Appl. Climatol., 122, 595-608, 2015.

Noetzli, J., Hoelzle, M., and Haeberli, W.: Mountain permafrost and recent Alpine rock-fall events: a GIS-based approach to determine critical factors, Permafrost, 2, 827-832, 2003.

Noetzli, J., Huggel, C., Hoelzle, M., and Haeberli, W.: GIS-based modelling of rock-ice avalanches from Alpine permafrost areas, Computat. Geosci., 10, 161-178, 2006.
Paranunzio, R., Laio, F., Nigrelli, G., and Chiarle, M.: A method to reveal climatic variables triggering slope failures at high elevation, Nat. Hazards, 76, 1039-1061, 2015.

Ravanel, L. and Deline, P.: Climate influence on rockfalls in highAlpine steep rockwalls: The north side of the Aiguilles de Chamonix (Mont Blanc massif) since the end of the "Little Ice Age", The Holocene, 21, 357-365, 2011.

Ravanel, L., Allignol, F., Deline, P., Gruber, S., and Ravello, M.: Rock falls in the Mont Blanc Massif in 2007 and 2008, Landslides, 7, 493-501, 2010.

Saez, J. L., Corona, C., Stoffel, M., and Berger, F.: Climate change increases frequency of shallow spring landslides in the French Alps, Geology, 41, 619-622, 2013.

Schär, C., Vidale, P. L., Luthi, D., Frei, C., Haberli, C., Liniger, M. A., and Appenzeller, C.: The role of increasing temperature variability in European summer heatwaves, Nature, 427, 332336, 2004.

Sosio, R., Crosta, G. B., and Hungr, O.: Complete dynamic modeling calibration for the Thurwieser rock avalanche (Italian Central Alps), Eng. Geol., 100, 11-26, 2008.

Stocker, T. F., Qin, D., Plattner, G.-K., Tignor, M., Allen, S. K., Boschung, J., Nauels, A., Xia, Y., Bex, V., and Midgley, P. M.: IPCC, 2013: Climate Change 2013: The Physical Science Basis. Contribution of Working Group I to the Fifth Assessment Report of the Intergovernmental Panel on Climate Change, IPCC, AR5, 1535, 2013.

Stoffel, M., Tiranti, D., and Huggel, C.: Climate change impacts on mass movements-case studies from the European Alps., Sci. Total Environ., 493, 1255-1266, 2014.

Tamburini, A., Villa, F., Fischer, L., Hungr, O., Chiarle, M., and Mortara, G.: Slope instabilities in high-mountain rock walls. Recent events on the Monte Rosa east face (Macugnaga, NW Italy), in: Landslide Science and Practice: Spatial Analysis and Modelling, 3, 327-332, 2013.

Turconi, L., Kumar De, S., Tropeano, D., and Savio, G.: Slope failure and related processes in the Mt. Rocciamelone area (Cenischia Valley, Western Italian Alps), Geomorphology, 114, 115128,2010

Viero, A., Furlanis, S., Squarzoni, C., Teza, G., Galgaro, A., and Gianolla, P.: Dynamics and mass balance of the 2007 Cima Una rockfall (Eastern Alps, Italy), Landslides, 10, 393-408, 2013.

WMO (World Meterological Organization): Guide to climatological practices (WMO-No. 100), 3rd Edn., Geneva, Switzerland, 180 pp., 2011.

Zemp, M., Haeberli, W., Hoelzle, M., and Paul, F.: Alpine glaciers to disappear within decades?, Geophys. Res. Lett., 33, L13504, doi:10.1029/2006GL026319, 2006. 